\title{
Subterranean biodiversity in the Serra da Bodoquena karst area, Paraguay river basin, Mato Grosso do Sul, Southwestern Brazil
}

\author{
Lívia Medeiros Cordeiro ${ }^{1,2}$, Rodrigo Borghezan ${ }^{1}$ \& Eleonora Trajano ${ }^{1}$ \\ ${ }^{1}$ Departamento de Zoologia, Instituto de Biociências da Universidade de São Paulo, CP: 11461, CEP: \\ 05422-970, São Paulo, SP, Brasil. http://www.ib.usp.br/ \\ ${ }^{2}$ Corresponding author: Livia Medeiros Cordeiro,e-mail: liviamc@hotmail.com
}

CORDEIRO, L. M., BORGHEZAN, R., TRAJANO, E. Subterranean biodiversity in the Serra da Bodoquena karst area, Paraguay river basin, Mato Grosso do Sul, Southwestern Brazil. Biota Neotropica. 14(3): e201400114. http://dx.doi.org/10.1590/1676-06032014011414

\begin{abstract}
We present herein a synthesis of faunistic data from caves in the Serra da Bodoquena karst area, middle Paraguay River basin, Mato Grosso do Sul State. Those include phreatic, submerged and dry caves. Emphasis is given to troglobites (exclusively subterranean species), potentially threatened due to their morphological, physiological and behavioral specializations, associated to generally small distributions. The Bodoquena karst area distinguishes as a spot of high diversity of troglobites, such as trichomycterid and heptapterid catfishes, aquatic planarians and gastropods, arachnids (Eusarcus opilionids, ctenid spiders), Polydesmida diplopods, several collembolans, some insects, and Peracarida crustaceans, which include interesting phylogenetic relicts as spelaeogriphaceans. Four geographic compartments corresponding to microbasins, seemingly with biogeographic importance for the subterranean fauna, are recognized. Phreatobic troglobites (Trichomycterus catfishes, aquatic peracarids, planarians) distribute widely across these compartments and some well beyond (the spelaeogriphacean Potiicoara brasiliensis reaches Mato Grosso state), while those living in base-level streams (Rhamdia and Ancistrus catfishes) and the terrestrial ones, that live in the vadose (aerated zone) are generally restricted to one compartment. Many subterranean ecosystems in Mato Grosso do Sul are endangered by several threats described here and urgent actions for effective protection are required to guarantee a sustainable use of the land and the karst aquifers.

Keywords: Subterranean biodiversity, troglobites, distribution, Serra da Bodoquena karst area, Mato Grosso do Sul, Biota-MS Program.
\end{abstract}

CORDEIRO, L. M., BORGHEZAN, R., TRAJANO, E. Biodiversidade subterrânea na área cárstica da Serra da Bodoquena, bacia do Rio Paraguai, Estado do Mato Grosso do Sul, Sudoeste do Brasil. Biota Neotropica. 14(3): e201400114. http://dx.doi.org/10.1590/1676-06032014011414

Resumo: Neste trabalho, são reunidos dados faunísticos sobre os táxons registrados em cavernas, freáticas, submersas e secas, da área cárstica da Serra da Bodoquena, na bacia do médio Rio Paraguai, Estado do Mato Grosso do Sul. É dada maior ênfase às espécies exclusivamente subterrâneas (troglóbias), potencialmente ameaçadas de extinção devido às especializações morfológicas, fisiológicas e comportamentais, e a distribuição geralmente restrita. A Serra da Bodoquena destaca-se por sua alta diversidade de troglóbios, entre peixes siluriformes, planárias aquáticas e gastrópodes, aracnídeos (opiliões Eusarcus, aranhas Ctenidae), diplópodes Polydesmida, diversos colêmbolos e alguns insetos, e crustáceos Peracarida, que incluem destacados relictos filogenéticos, como os crustáceos Speleogriphacea e anfípodes Megagidiella. São reconhecidos quatro compartimentos de aparente relevância biogeográfica para cavernícolas, correspondendo a microbacias na área. Troglóbios freáticos (bagres Trichomycterus, crustáceos Peracarida aquáticos, planárias) apresentam distribuições amplas através desses compartimentos, atingindo áreas distantes, como o Mato Grosso no caso dos Spelaeogriphacea Potiicoara brasiliensis, enquanto as espécies aquáticas que vivem em riachos (siluriformes como Rhamdia e Ancistrus) e os terrestres em geral, que vivem na zona vadosa, descontínua, tendem a apresentar distribuições restritas aos respectivos compartimentos. Muitos ecossistemas subterrâneos do Mato Grosso do Sul estão vulneráveis às várias ameaças descritas aqui e ações urgentes de proteção efetiva são necessárias para garantir uma utilização sustentável da terra e dos aquíferos cársticos.

Palavras-chave: biodiversidade subterranean, troglóbios, área cárstica da Serra da Bodoquena, Mato Grosso do Sul, Programa Biota-MS. 


\section{Introduction}

The Serra da Bodoquena karst area has ca. 200 caves so far recorded (Sallun-Filho et al. 2010), with a great variety of subterranean habitats, including phreatic (never exposed at the vadose zone - Ford \& Williams 2007) and submerged (found beneath the water level after a period at the vadose zone) cave systems, and dry caves. It distinguishes as a high diversity spot for troglobites (species with exclusively subterranean source populations - Trajano 2012) in South America. Among these, five siluriform fishes and several invertebrates have been recorded, such as spelaegriphaceans and bogidiellid amphipods, planarians, Pomatiopsidae gastropods, polydesmid diplopods, opilionids and onychophorans, including phylogenetic and geographic relicts. In addition, a rich troglophilic (also found in epigean habitats) fauna is observed, which coexists and interacts with the several troglobitic populations. Such diversity points to intricate evolutionary patterns related to the complex geological history of the area, interacting with present-day ecological factors, including the epigean (surface) biodiversity and biomass allowing for a significant input of nutrients into the subterranean realm.

\section{History of speleobiology in the Mato Grosso do Sul State}

The speleobiological interest in the area started in the mid1980 's, with the discover, in a submerged cave (the Lago Azul Cave), followed by description of Potiicoara brasiliensis Pires 1987, the second known species of living Spelaeogriphacea - the first one was Spelaeogriphus lepidops Gordon 1957, from Table Moutains, South Africa (there are recent reports from caves other than the type locality - S. Craven \& A.L.F. Guil, pers. comm.). Later on, two other species were found in Australia, confirming the Gondwanic distribution for the taxon and its relictual character. Further studies showed a wide distribution for spelaeogriphaceans in Mato Grosso do Sul, and also brought into light another phylogenetically and biogeographically important crustacean, the Megagidiella amphipods.

The period from mid-1990's to mid-2000's was marked by cave diving by biologists, who found the first troglobitic fishes from Serra da Bodoquena karst area, Bonito County, in the southern plateau: the armored catfish Ancistrus formoso Sabino \& Trajano 1997 and Trichomycterus dali Rizzato, Costa-Jr., Trajano \& Bichuette 2011 (this fish was first collected in 1998, but its description took more than one decade to be published).

In the early 1990's, extensive biologic surveys were made, focusing mainly on terrestrial cave communities, which resulted in the first comprehensive faunal lists for caves in the southern plateau of the Bodoquena karst area, Bonito, Jardim and Porto Murtinho counties (Gnaspini \& Trajano 1994). By then, the high potential for the occurrence of specialized terrestrial and aquatic subterranean animals was clear.

The presence of several spectacular submerged and phreatic caves, for which the Bonito region is notorious worldwide, implied an increasingly strong touristic pressure over the area. Brazilian legislation requires management plans for caves destined for tourism and their surroundings. Hence, environmental studies were designed to base such plans, beginning with the most famous touristic point, the flooded cave Lago Azul, where Potiicoara brasiliensis was discovered. Such studies allowed for a better knowledge of the aquatic communities in some caves, such as Mimoso, Buraco das Abelhas, São Miguel and Anhumas, besides the Lago Azul.

In 2002, N. Moracchioli finished her Ph. D. thesis centered on Brazilian spelaeogriphaceans, which proved to be quite abundant and widespread in Serra da Bodoquena, also occurring in Ricardo Franco Cave, Forte Coimbra area, Corumbá Co. (also in Mato Grosso do Sul, but on the opposite margin of the Paraguay river, distant ca. $200 \mathrm{~km}$ from Bodoquena), and in Curupira cave, Serra das Araras, Rosário do Oeste County, in Mato Grosso state, to the north of Mato do Grosso do Sul. She also gathered data on Megadiella amphipods, which co-occur with spelaeogriphaceans in most localities, including Ricardo Franco, but not Curupira cave. Ricardo Franco Cave is historically important because it was the first Brazilian cave mentioned in a written document, a poem by Dom Aquino Corrêa, from the late 1700's (Martin 1980) - Harta figueira à porta. Entrada bruta./ Desço. Horrido hypogeum! Antro sombrio!/ Mas, de repente, um mágico arrepio,/ A luz das tochas. Tímida, a alma escruta.../... In 2000, that big fig tree was still at the cave entrance. As far as we know, this cave was not studied by biologists before their visit.

The studies above were carried out basically by researchers from the Universidade de São Paulo - USP, since there was no autochthonous academic speleobiology in Mato Grosso do Sul. In 2008, L. M. Cordeiro finished her M.Sc. dissertation, presented at the Universidade Federal do Mato Grosso do Sul UFMS, which significantly enlarged the faunistic knowledge on the Bodoquena subterranean communities, in terms of new records for previously studied caves and new caves visited, including several in the northern plateau, reaching higher altitudes. She also performed the first detailed ecological study on cave terrestrial invertebrate communities in the area. As the result of a joint effort with Rodrigo Borghezan, student at the UNIDERP (MS), two additional new troglobitic fishes were found by these pioneers works on speleobiology in Mato Grosso do Sul, the heptapterid Rhamdia Bleecker 1858, (description is in progress) and the second troglobitic Ancistrus Kner 1845, known for the area. These species have been first studied by R. Borghezan for his undergraduate monograph (Borghezan 2008) and, later on, for his M.Sc. dissertation at the Universidade de São Paulo (Borghezan 2012).

We present here a synthesis of the faunal knowledge on the subterranean ecosystems in two karst areas of Mato Grosso do Sul, the intensively studied Serra da Bodoquena and the less known Forte Coimbra, based on published and unpublished data from the last two decades, as well as studies in progress, discussing the main threats for this highly relevant fauna.

\section{Study site}

The Serra da Bodoquena is one of the most extensive continuous Brazilian karst areas, located in the Mato Grosso do Sul state, in central-western Brazil. It consists of a northsouth plateau extending for approximately $200 \mathrm{~km}$, which forms an important water divide with an altitude around $800 \mathrm{~m}$ (Figure 1). It is unique in the context of the Brazilian Platform, because tectonic activities have been recognized in the area in the context of the Paraguay Belt and related to the development of the Cenozoic Pantanal Basin, which is still subsiding (SallunFilho \& Karmann 2009, Campanha et al. 2011). Rains are concentrated in November to February, with a mean average 


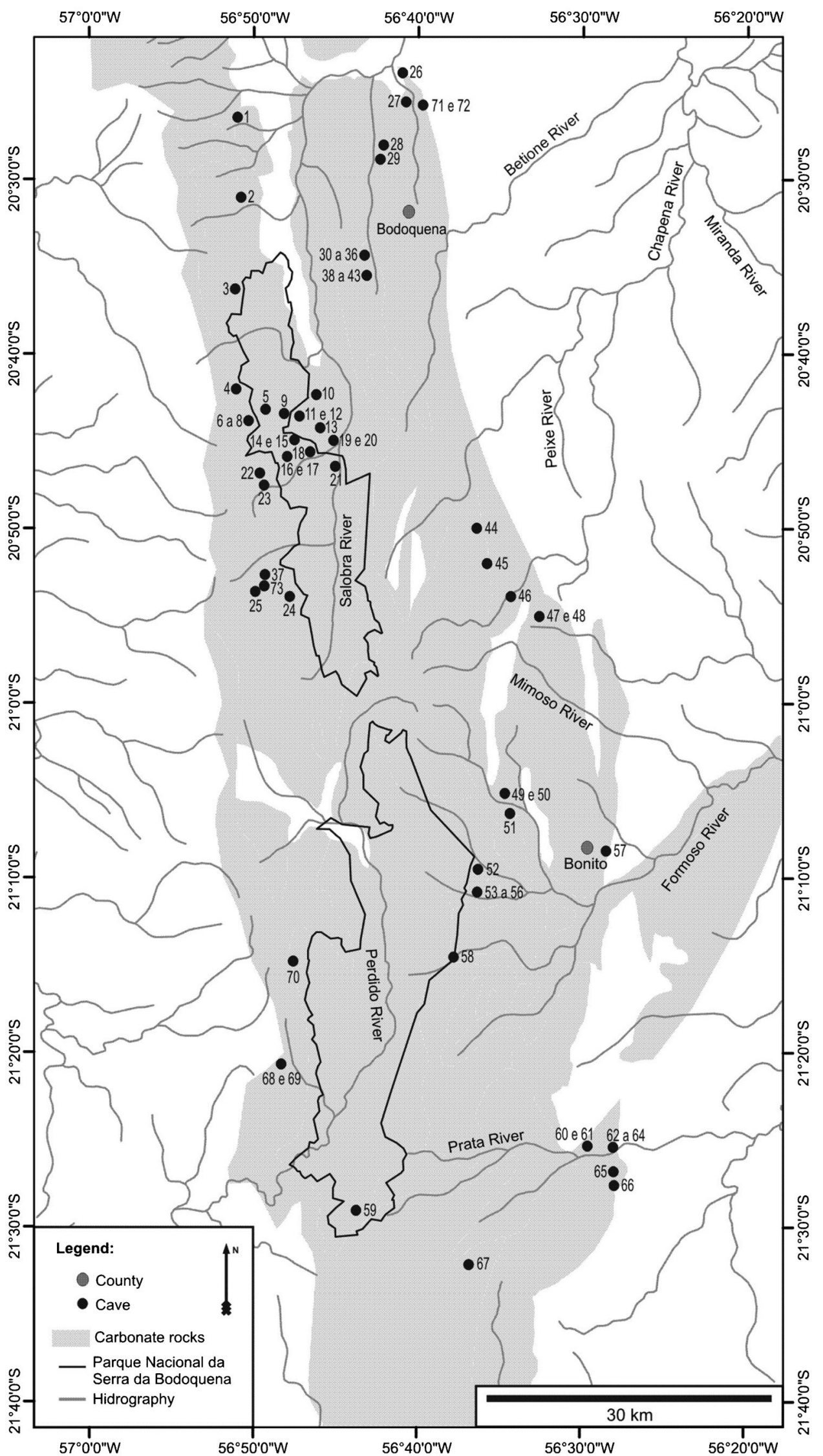

Mato Grosso do Sul State with Serra da Bodoquena karst area

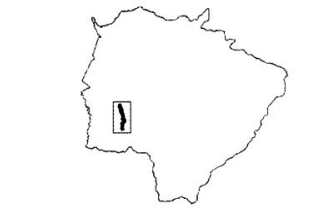

1 - Urubu Re

2 - Mina do Veio

3 - Antenor

4 - California

5 - Toca da Onça

6 - Sistema Ouro Verde

7 - Curvadinha

8 - Fendão

9 - Seu Valdemar

10 - Nasc. do Salobrinha

11 - Pai Adão III

12 - Sr. Natal

13 - Mina do Seu Jesus

14 - Dente de Cão

15 - Explorada

16 - Toca da Trilha

17 - Flor da Bodoquena

18 - Bacuri

19 - Córrego Azul I

20 - Córrego Azul III

21 - Morro do Jericó

22 - Mina da Sede

23 - Bebedouro

24 - Saracura

25 - José Cesário

26 - Clarão

27 - Estreito da Serra

28 - Campina II

29 - Cerâmicas

30 - Buraco do Bicho

31 - Dona Benedita

32 - Manoel Cardoso

33 - Fadas

34 - Cinco de Ouros

35 - Paquinha

36 - Mico

37 - Gaúcho

38 - Mulher

39 - Quatro Irmãos

40 - Alex I

41 - Alex II

42 - Azedinha I

43 - Azedinha II

44 - Nasc. da Ceita Curê

45 - Pitangueiras

46 - Mimoso

47 - Ametista

48 - João Arruda

49 - Nossa Sra. Aparecida

50 - Jaraguá

51 - São Miguel

52 - Guaviral

53 - Lago Azul

54 - Barro Preto

55 - Anhumas

56 - Portal

57 - Morro do Matheus

58 - Nasc. do Rio Formoso

59 - Buraco das Abelhas

60 - Vale do Prata

61 - Dona Matilde

62 - X-Coqueiro

63 - Poço

64 - Santa Maria

65 - Cure

66 - Lagoa Misteriosa

67 - Buraco do Japonês

68 - Curvelo

69 - Curvelinho

70 - Harmonia

71 - Três Morrinhos

72 - Ind. Camargo Corrêa

73 - Patrimônio

Figure 1. Map of the Serra da Bodoquena karst area, showing the localization of the studied caves (Modified from Bizzi et al. 2001). / Figura 1: Mapa da área cárstica da Serra da Bodoquena com a localização das cavernas estudadas (Modificado de Bizzi et al. 2001). 
precipitation of about $1,300 \mathrm{~mm}$ per year and a mean annual temperature of $24^{\circ} \mathrm{C}$. The natural vegetation consists of savanna in contact with semi-deciduous seasonal forest (Boggiani \& Clemente 1999, Scremin-Dias et al. 1999).

At the eastern highland (greater than $500 \mathrm{~m}$ a.s.1.) the Bodoquena Plateau is divided into two main compartments, well defined by geomorphological contrasting features: the southern sector (Perdido River area), which has mainly karst landforms; and the northern part (Salobra River area), which has more fluvial characteristics. In the western lowlands (less than 500 a.s.1.), the Miranda river Depression forms exposed karst systems and part of a separate system of subjacent karst (Sallun-Filho \& Karmann 2007). Geological evidence indicates that the karst aquifer is recharged mainly by autogenic waters, promoting the intense deposition of carbonates (as tufa deposits) as a consequence of resurgence of saturated waters (Sallun-Filho et al. 2004).

Most caves included in the present study are within the limits of the Parque Nacional da Serra da Bodoquena (PNSB), with 76.481 ha., created in 2000. Four rural settlements have been established in the surroundings of the PNSB at least 20 years ago, where several relevant caves harboring endemic troglobites are located. The livestock is currently the main economic activity in the region, although the tourism, including speleotourism, has an increasing economic importance, especially in Bonito, Bodoquena and Jardim counties.

\section{Methods}

Part of the data herein gathered were compiled from the literature, including publications such as the faunistic inventories (Gnaspini \& Trajano 1994, Pinto da Rocha 1995, Pintoda-Rocha \& Sossegolo 2001, Galati et al. 2003, Costa-Jr. 2004, Eriksson \& Gonçalves 2010) and taxonomy-oriented works (Trajano et al. 2000, Andrade et al. 2001, Mahnert 2001, Labruna \& Venzal 2009, Pires-Vanin 2012), in addition to unpublished dissertations (Moracchioli 2002, Cordeiro 2008) and grey literature (Godoy 1986, Gnaspini et al. 1994). Original data came from collections by several speleobiologists in different occasions, including field courses, and more detailed identifications of material cited in the literature. For the sake of simplicity, we did not distinguish the source of data in the tables. Details on geographic coordinates of the caves listed in present work can be accessed at $\mathrm{CNC} / \mathrm{SBE}$ link (Cadastro Nacional de Cavernas / Sociedade Brasileira de Espeleologia www.cavernas.org.br/cnc).

In general, terrestrial organisms were collected by hand during visual inspections of all accessible substrates, using small brushes and tweezers. Pitfall-traps were used in some caves (Dente de Cão, Mateus, Córrego Azul I, Córrego Azul III, Sr. Natal, Fadas, Pitangueiras). Aquatic animals were collected with hand nets, bottles and baited minnow traps, from outside the water and during free and scuba diving. Surbers $30 \times 30 \mathrm{~cm}$ were used for sampling benthonic organism in the Urubu Rei Cave.

Specimens were preserved in the proper solutions and brought to the laboratory for identification. Fishes were killed by over-anesthesia using benzocaine, fixed in formalin $4 \%$, and preserved in alcohol $70 \%$. Some samples were fixed in alcohol $100 \%$ for future molecular studies.

We did not use parataxonomy. Morphoespecies, when cited, have been identified by specialists on the taxonomy of the respective groups. Otherwise, the identifications are provided at the lowest level (usually supraespecific) reliable by nonspecialists. Therefore, the number of species is probably much higher than shown in the tables.

The collecting efforts were highly heterogeneous. Most caves were sampled on a few occasions, generally during the dry seasons and on different years. A few caves were studied on several, consecutive occasions, both during dry and rainy seasons, such as the Córrego Azul I, Córrego Azul III, Fadas and Sr. Natal caves (4-5 occasions on 2006-2007; Cordeiro 2008); sampling with surber were carried out on eight occasions in the Urubu Rei Cave (2010-2012; L. M. Cordeiro, in progress). Therefore, differences in the number of taxa recorded in the tables do not necessarily reflect differences in biodiversity among caves.

The species/populations were classified according the Schiner-Racovitza system, following definitions in Trajano (2012): 1. troglobites correspond to exclusively subterranean source populations (a source populations has excess production and continues to grow if isolated); sink populations (a sink population, if cut off from all other migrants, eventually becomes extinct) may be found in surface habitats; 2 . troglophiles include source populations both in hypogean and epigean habitats, with individuals regularly commuting between these habitats, promoting the introgression of genes selected under epigean regimes into subterranean populations (and vice-versa); 3. trogloxenes are instances of source populations in epigean habitats, but using subterranean resources.

\section{Results}

The taxa so far recorded for 84 caves visited in the Serra da Bodoquena karst area are presented in tables 1 and 2 (troglobites, found in 43 out of those caves) and in tables 3 to 9 (the remaining taxa); in addition, tables 1,2 and 8 (Psychodidae dipterans) include caves in the poorly known Corumbá karst area, respectively Ricardo Franco and Forte Junqueira caves, situated ca. $200 \mathrm{~km}$ to the northwest of Bodoquena, at the border with Bolivia. The geographic location of studied caves is shown in Figure 1, except for 16 caves, for which there are no coordinates.

The diversity of some taxa, especially mites and ants, is not accurately represented due to taxonomic impediment: only the few identifications below the Order (for Acari) or Family (for the widespread formicids) levels were included in the tables.

As expected, the highest diversities were observed in the most intensively studied caves, in different occasions and seasons, and using different, complementary methods: Córrego Azul I e III, Fadas, Pitangueiras, João Arruda, Nossa Senhora Aparecida, São Miguel e Lago Azul.

\section{Discussion}

\section{Distribution patterns and diversity}

The subterranean fauna from the Bodoquena karst area has a unique taxonomic composition, combining typically subtropical (e.g., oniscodesmid diplopods) and tropical (e.g., Amblypygids, Eusarcus opilionids, isopterans, Bogidiellid amphipods), with (so far) exclusive elements (e.g., troglophilic and troglobitic onychophorans), including phylogenetic relicts, such as spelaeogriphaceans and Megagidiella amphipods. Geographic relicts include Trichomycterus catfish, not found 
Subterranean biodiversity in the Serra da Bodoquena

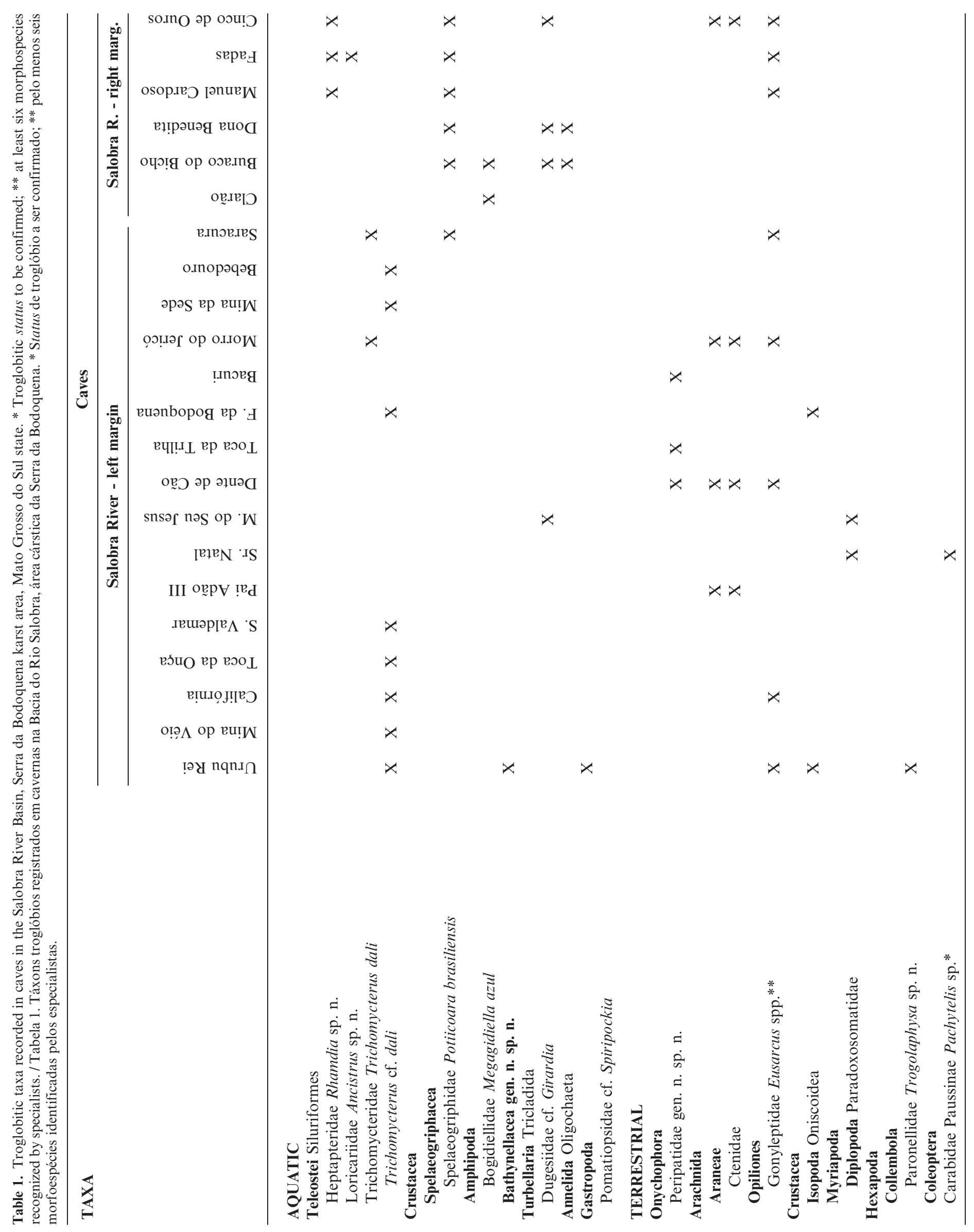


Cordeiro L.M. et al.




Biota Neotrop., 14(3): e201400114, 2014

7

Subterranean biodiversity in the Serra da Bodoquena

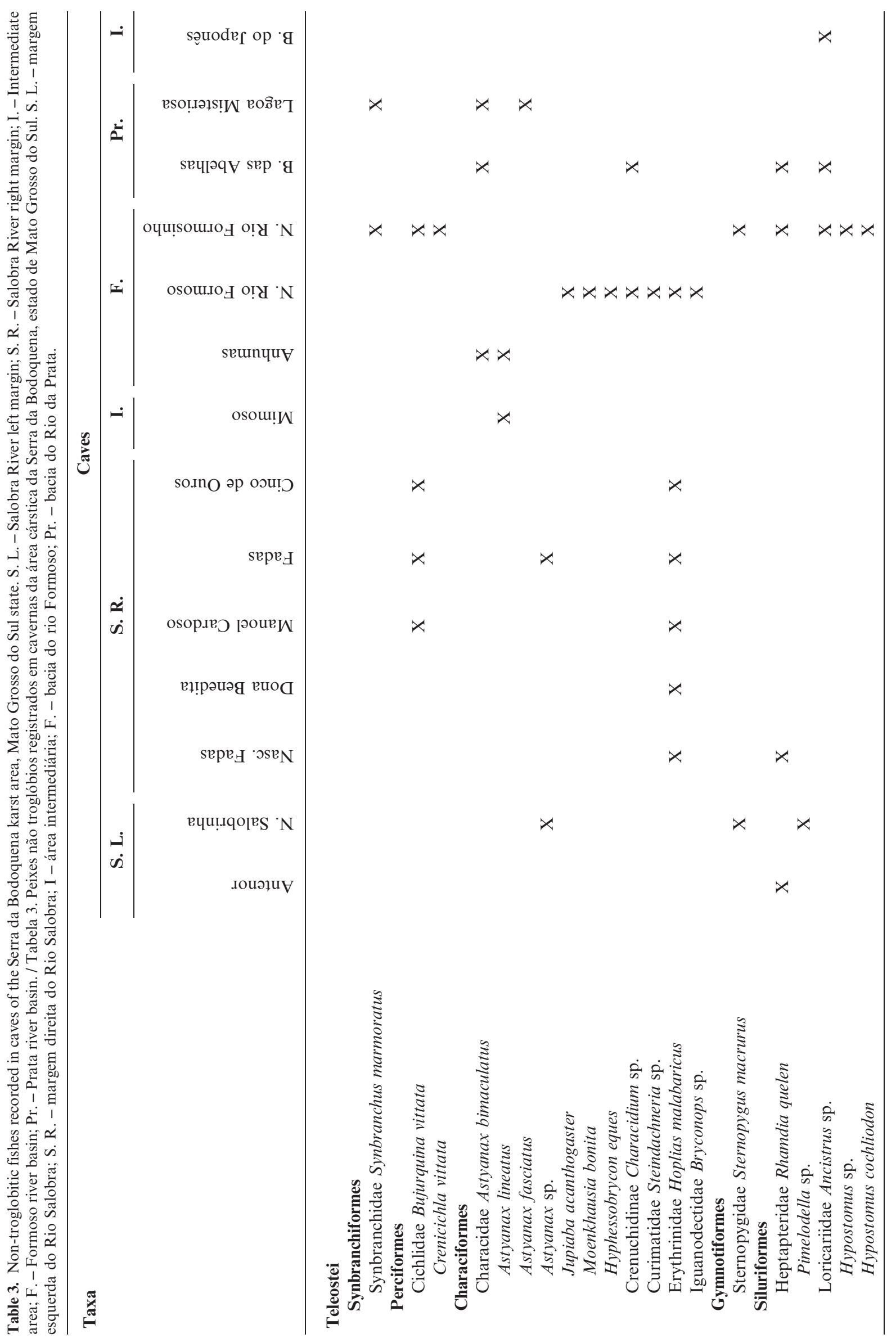

http://dx.doi.org/10.1590/1676-06032014011414

http://www.scielo.br/bn 
Cordeiro L.M. et al.

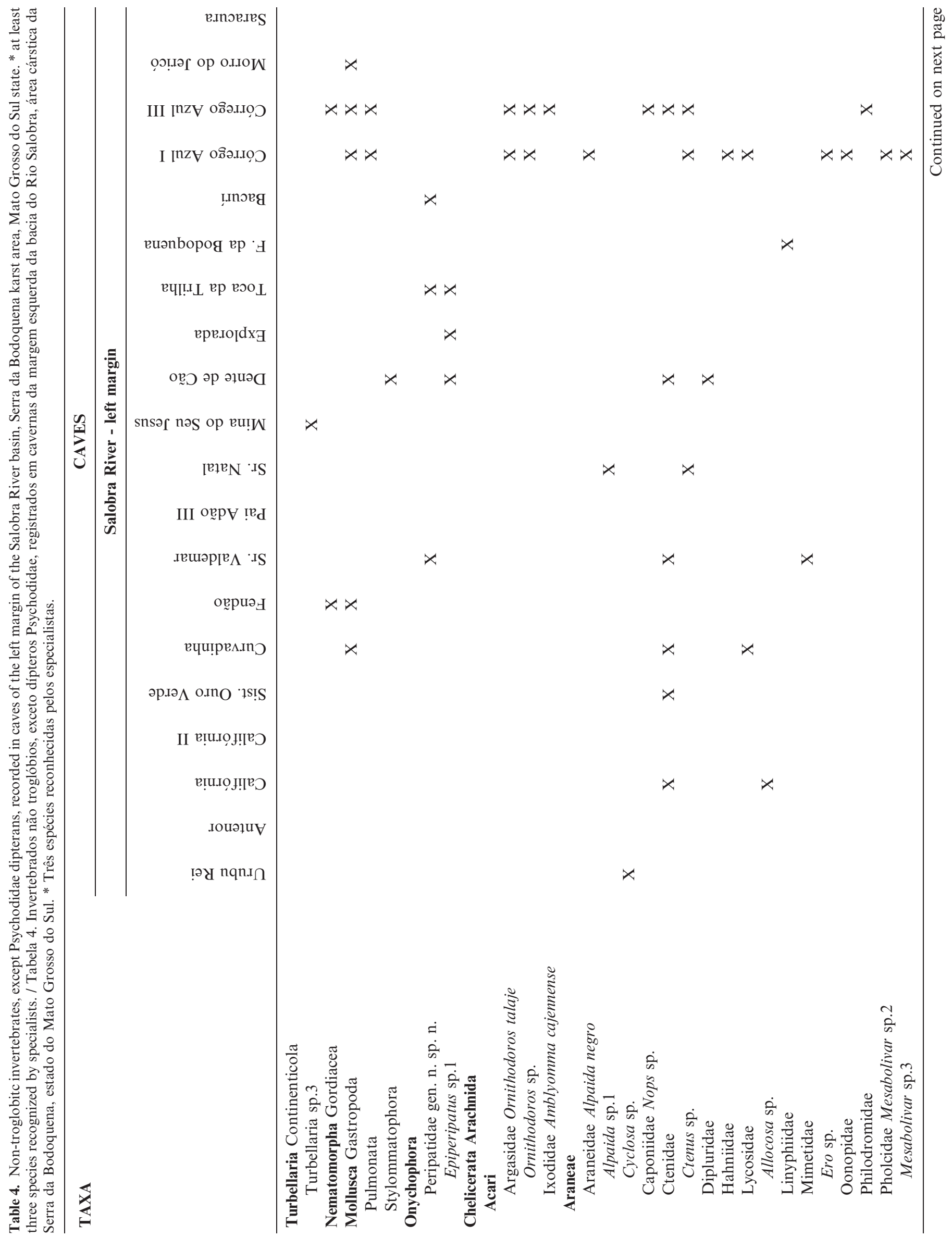


Subterranean biodiversity in the Serra da Bodoquena




Cordeiro L.M. et al.




Subterranean biodiversity in the Serra da Bodoquena

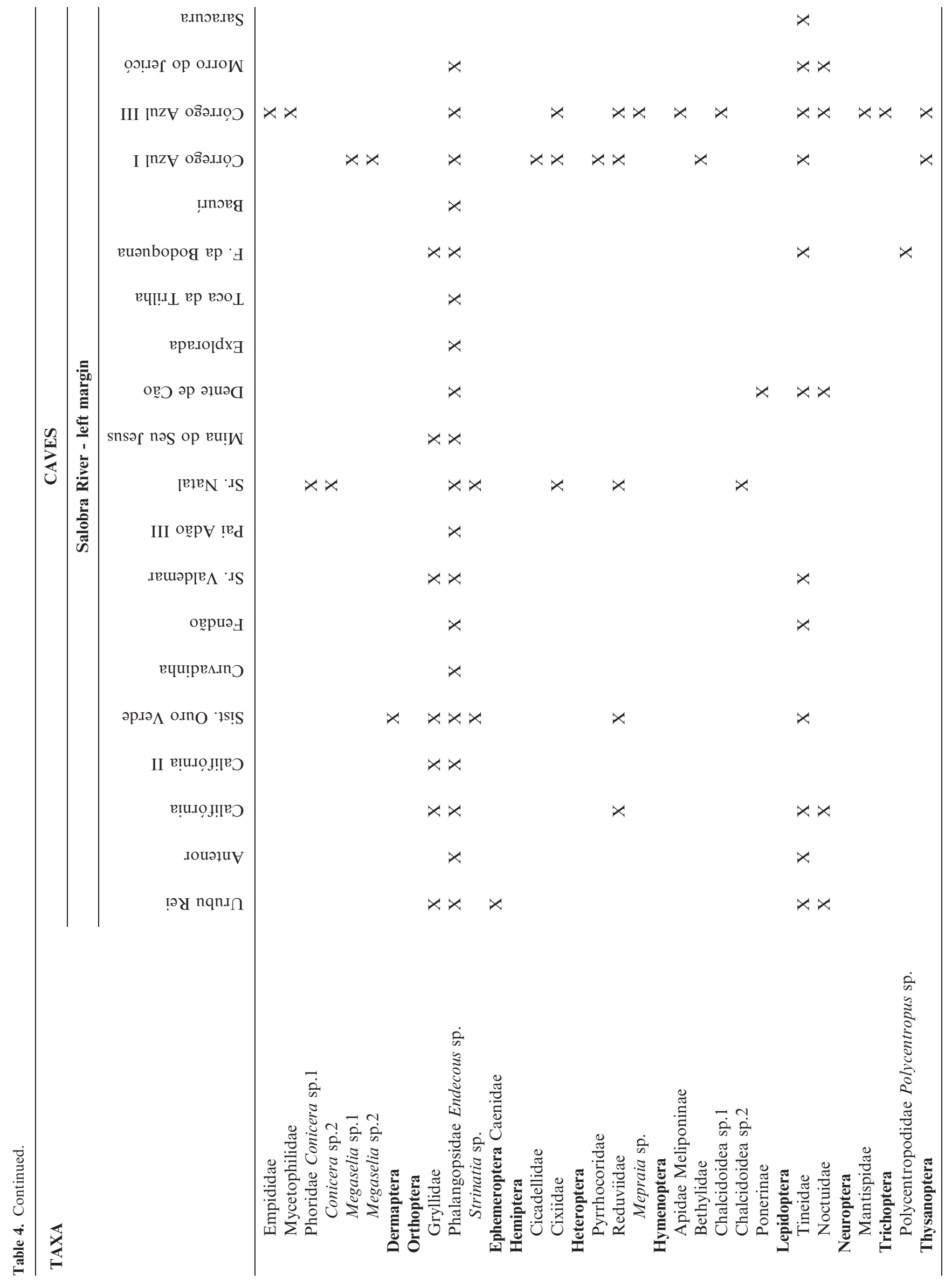


Cordeiro L.M. et al.

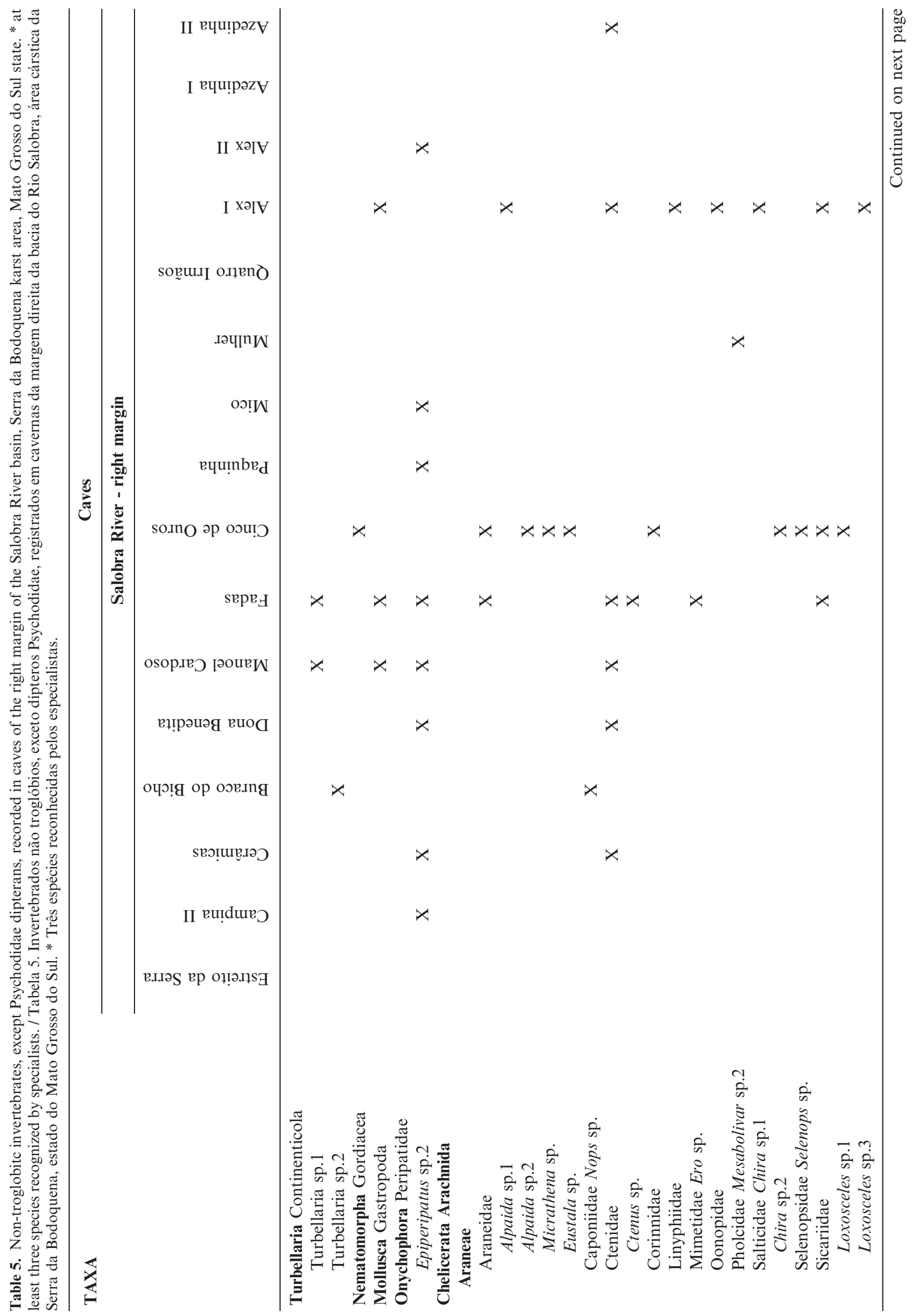


Subterranean biodiversity in the Serra da Bodoquena

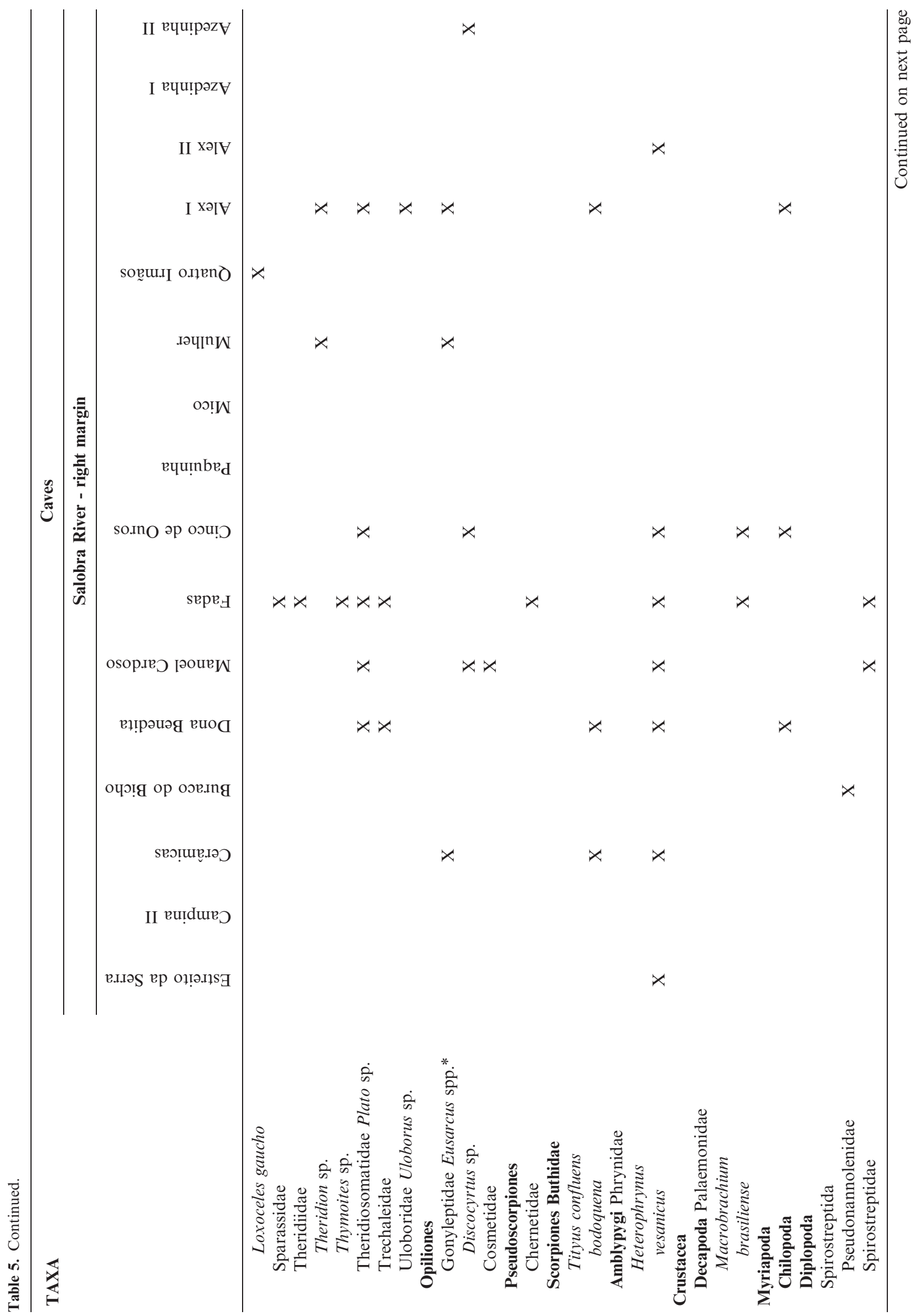


Cordeiro L.M. et al.

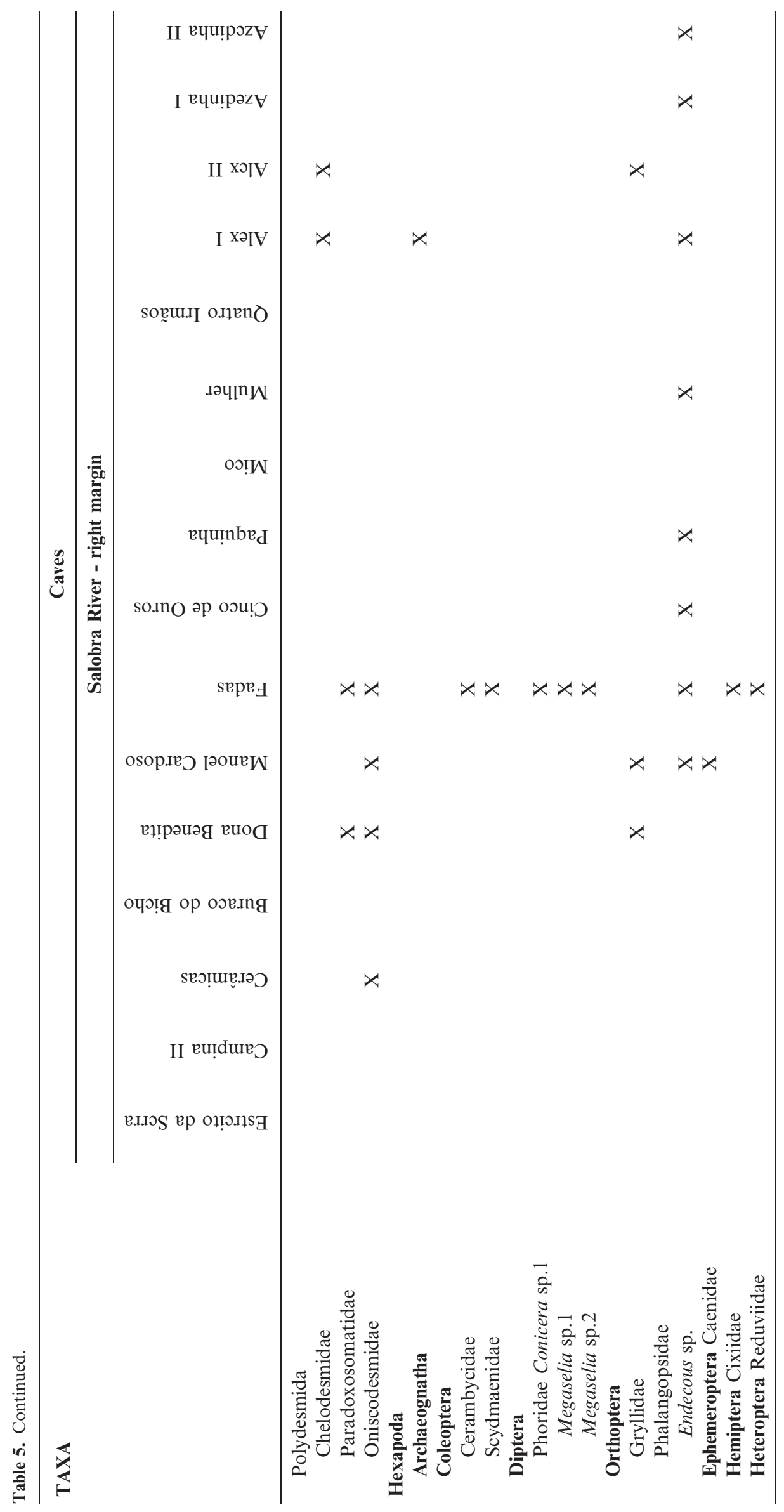


Table 6. Non-troglobitc invertebrates, except Psychodidae dipterans, recorded in caves of the Formoso, Prata and Perdido river basins and intermediate areas of the Serra da Bodoquena karst area, Mato Grosso do Sul state. * Identified as Blechroscelis in Pinto-da-Rocha (1995); ** at least three species recognized by specialists. / Tabela 6. Invertebrados não troglóbios registrados em cavernas das bacias dos rios Formoso, Prata e Perdido e áreas intermediárias do carste da Serra da Bodoquena, estado de Mato Grosso do Sul. * Identificado como Blechroscelis em Pinto-daRocha (1995); ** pelo menos três espécies reconhecidas pelos especialistas.

TAXA

\section{Caves}

Annelida Oligochaeta

Mollusca Gastropoda

Pulmonata

Stylommatophora

Subulinidae

Camaenidae Solaropsis sp.

Megalobulimus cf. oblongus

\section{Chelicerata Arachnida}

Acari

Argasidae Carios fonsecai

Ornithodoros talaje

Ornithodoros sp.

Oribatida

\section{Araneae}

Amaurobiidae Metaltella sp.

Araneidae

Alpaida alto

Ctenidae Ctenus aff. griseolus

Ctenus sp.

Isoctenus $\mathrm{sp}$.

Nothroctenus sp.

Phoneutria nigriventer

Lycosidae

Mysmenidae Mysmena sp.

Oonopidae Oonops sp.

Orchestina sp.

Pholcidae

Mesabolivar sp.4

Mesabolivar sp.5

Mesobolivar sp.6*

Scytodidae

Scytodes globula

Sicariidae

Loxosceles sp. 2

Loxoceles gaucho

Loxoceles grupo gaucho

Loxoceles similis

Theridiidae

Achaearanea sp.

Theridiosomatidae Plato sp.

Titanoecidae

Opiliones

Gonyleptidae Eusarcus spp.** Parabalta sp.

Cosmetidae

\section{Formoso River}

\begin{tabular}{|c|c|c|c|c|c|c|c|c|c|}
\hline \multicolumn{10}{|c|}{ Formoso River } \\
\hline 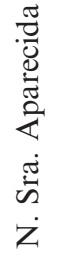 & 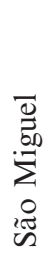 & 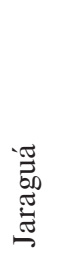 & 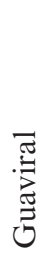 & 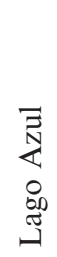 & 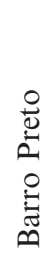 & 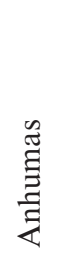 & $\begin{array}{l}\text { त्ञ } \\
0 \\
0\end{array}$ & 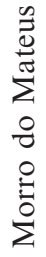 & $\begin{array}{l}0 \\
0 \\
0 \\
\Xi \\
0 \\
0 \\
1 \\
0 \\
0 \\
z \\
z\end{array}$ \\
\hline
\end{tabular}

X

X

X

X

$\begin{array}{ccccc}X & X & X & X \\ X & & & \\ & X & X & & \end{array}$

X

X

X

$\mathrm{X}=\mathrm{X}$

$\begin{array}{llllll} & & X & & \\ X & X & X & X & X & X \\ X & & & & \\ \text { X } & & & \\ \text { X } & & & \\ \text { X } & & \end{array}$

X

X

X

X

X

X

$\mathrm{X}$

X

X

X

X

X

X

X

X

X

X X

X

X

X

$\mathrm{X}$

$\mathrm{X}$

X

X

X

X

X $\quad \mathrm{X}$ 
Table 6. Continued.

TAXA

\section{Caves}

\section{Formoso River}

\begin{tabular}{|c|c|c|c|c|c|c|c|c|c|}
\hline 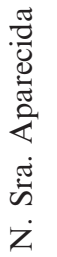 & 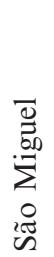 & 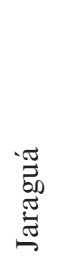 & 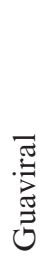 & 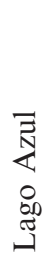 & $\begin{array}{l}0 \\
\stackrel{0}{0} \\
0 \\
0 \\
0 \\
0 \\
\mathscr{D}\end{array}$ & $\frac{\tilde{Z}}{\stackrel{\Xi}{\Xi}}$ & 胥 & 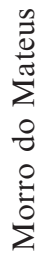 & 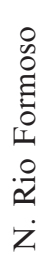 \\
\hline
\end{tabular}

\section{Pseudoscorpiones}

Chernetidae Spelaeochernes dubius Spelaeochernes eleonorae Spelaeochernes sp.

Amblypygi

Prhynidae Heterophrynus vesanicus

Crustacea

Isopoda

Armadillidae Venezillo sp.

Diplopoda

Spirostreptida

Pseudonannolenidae

Spirostreptidae

Orthoporus sp.

Polydesmida

Chelodesmidae Arthrosolaenomeris sp.

Oniscodesmidae Crypturodesmus sp.

Cryptodesmidae Cryptodesmus sp.

Hexapoda

Collembola

Arrhopalitidae Arrhopalites sp.

Entomobryidae

Paronellidae

Coleoptera

Carabidae Galerita collaris

Dytiscidae

Cholevidae Dissochaetus murray

Scarabaeidae Megasoma sp.

Staphylinidae

Diptera

Cecidomyiidae

Chironomidae

Culicidae Subf. Culicinae

Drosophilidae Drosophila eleonorae

Drosophila sp.

Muscidae

Mycetophilidae

Keroplatidae

Phoridae

Conicera sp. 3

Megaselia sp. 3

Sphaeroceridae

Tipulidae

Orthoptera

Phalangopsidae

Endecous sp.

Hemiptera

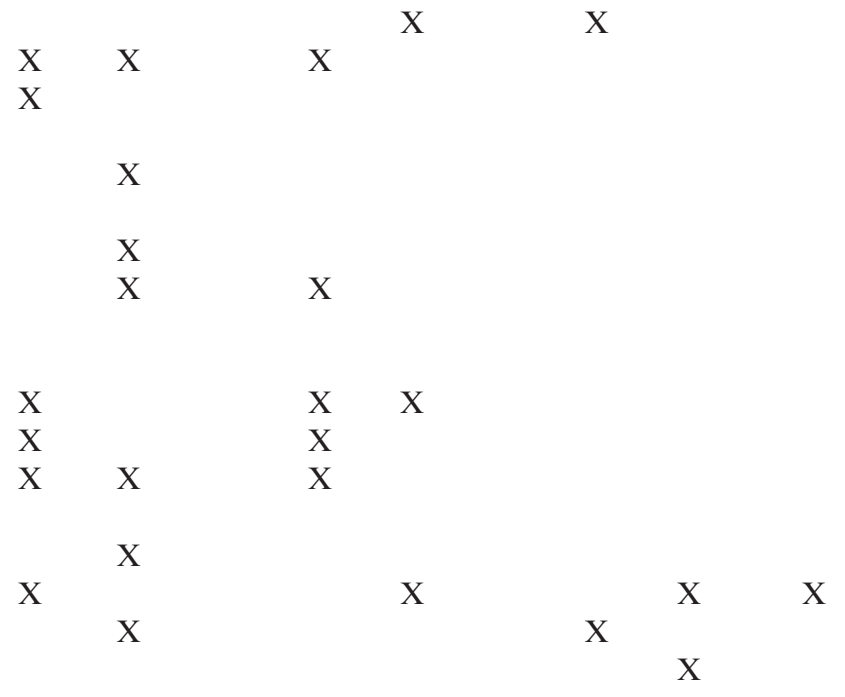

X

$\begin{array}{lll}X & \\ X & X & X\end{array}$

X

$\mathrm{X} \quad \mathrm{X}$

X

X

$\begin{array}{lll} & X \\ X & X & X \\ & & X \\ & X & X \\ & X & X\end{array}$

X

X

$\mathrm{X}$

X

X

X

X

X 
Table 6. Continued.

\begin{tabular}{|c|c|c|c|c|c|c|c|c|c|c|}
\hline \multirow[t]{3}{*}{ TAXA } & \multicolumn{10}{|c|}{ Caves } \\
\hline & \multicolumn{10}{|c|}{ Formoso River } \\
\hline & 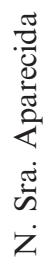 & 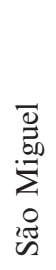 & 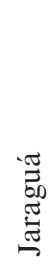 & 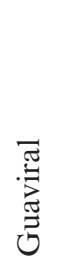 & 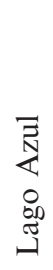 & 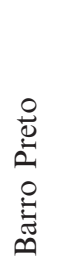 & $\begin{array}{l}\text { 号 } \\
\text { 吾 } \\
\text { 完 }\end{array}$ & $\begin{array}{l}\text { चु } \\
\stackrel{0}{0} \\
0\end{array}$ & 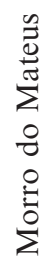 & $\begin{array}{l}0 \\
0 \\
0 \\
0 \\
0 \\
\text { I } \\
o \\
\text { a } \\
z \\
z\end{array}$ \\
\hline Cicadellidae & & $\mathrm{X}$ & & & & & & & & \\
\hline Derbidae & & $\mathrm{X}$ & & & & & & & & \\
\hline \multicolumn{11}{|l|}{ Heteroptera } \\
\hline Gerridae & & & & & $\mathrm{X}$ & & & & & \\
\hline Veliidae & & & & & & & $\mathrm{X}$ & & & \\
\hline Belostomatidae & & & & & $\mathrm{X}$ & & & & & \\
\hline Coreidae & & & & & $\mathrm{X}$ & & & & & \\
\hline Reduviidae & & $\mathrm{X}$ & & & $\mathrm{X}$ & & & & & \\
\hline Emesinae & & $\mathrm{X}$ & & & & & & & & \\
\hline \multicolumn{11}{|l|}{ Hymenoptera } \\
\hline Braconidae & $\mathrm{X}$ & & & & & & & & & \\
\hline Ichneumonidae & & $\mathrm{X}$ & & & & & & & & \\
\hline Solenopsis grupo geminata & & $\mathrm{X}$ & & $\mathrm{X}$ & & & & & & \\
\hline Vespidae & $\mathrm{X}$ & $\mathrm{X}$ & $\mathrm{X}$ & & & & & & & \\
\hline Polybia ignobilis & & $\mathrm{X}$ & & & & & & & & \\
\hline Isoptera & $\mathrm{X}$ & $\mathrm{X}$ & & & $\mathrm{X}$ & & & & & \\
\hline Nasutiterminae Nasutitermes sp. & & $\mathrm{X}$ & & & & & & & & \\
\hline \multicolumn{11}{|l|}{ Lepidoptera } \\
\hline Tineidae & $\mathrm{X}$ & $\mathrm{X}$ & & $\mathrm{X}$ & $\mathrm{X}$ & $\mathrm{X}$ & & & & \\
\hline Noctuoidea & $\mathrm{X}$ & $\mathrm{X}$ & $\mathrm{X}$ & & & & & & & \\
\hline Noctuidae & & $\mathrm{X}$ & & $\mathrm{X}$ & & $\mathrm{X}$ & & & & \\
\hline Psocoptera & $\mathrm{X}$ & & & $\mathrm{X}$ & $\mathrm{X}$ & & & & & \\
\hline Psyllipsocidae & & $\mathrm{X}$ & & & & & & & & \\
\hline
\end{tabular}

in epigean water courses until now. Widespread taxa with troglobitic representatives in other karst areas include gastropods, and the several families of Collembola, a very ubiquitous group in caves worldwide. On the other hand, the low diversity of carabid beetles and oniscidean isopods, taxa usually abundant and diversified in most Brazilian caves, is unexpected.

When compared to other karst areas in Brazil, the Bodoquena distinguishes as a spot of high diversity of troglobites, together with the Alto Ribeira, in São Paulo state, and Serra do Ramalho, São Desidério and Chapada Diamantina, in Bahia state.

Among aquatic troglobites (also referred as stygobites), those occurring in the phreatic zone, such as spelaeogriphaceans, amphipods, planarians and Trichomycterus catfish, have a wide distribution across the sectors defined by the microbasins, indicating a connection across the aquifer, at least in the past. On the other hand, aquatic species living in base-level streams (for a habitat definition, see Trajano, 2001), such as Rhamdia n. sp. and Ancistrus n. sp. from Fadas system, and a new gastropod species, which may be the second reported to genus Spiripockia, present a locally restricted distribution. As well, terrestrial troglobites generally occur in caves in the same microbasin, probably due to fragmentation of the vadose (aerated) zone.
A higher degree of fragmentation may explain the higher diversity of terrestrial troglobites in the north plateau. SallunFilho \& Karmann (2007) defined the Salobra River area as a canyons and alluvial plains (CAP). In fact, the Salobra base level already reached the impermeable substrates by the fluvial incision at times cutting down to the noncarbonated rocks (Sallun-Filho \& Karmann 2007). This would explain the occurrence of different species of taxa as ctenid spiders, onychophorans and Eusarcus opilionids separated by the river valley (mostly a canyon).

As expected, many typically tropical taxa are more frequent in the north plateau, e.g., onychophorans, amblypygids, Eusarcus opilionids (also highly diversified in caves from Goiás and Bahia states - M.E. Bichuette, pers. comm., 2012). Troglophilic taxa widespread in Brazilian caves include Loxosceles, Plato, Mesabolivar and ctenid spiders, Endecous crickets, Conicera and Megaselia phorids.

The Serra da Bodoquena may be the southern limit of the distribution area of Heterophynus vesanicus, typical Cerrado species (A. Giuponni, pers. comm.). Females with eggs were observed in several caves during the dry season, which seems to correspond to the reproductive peak for the species in the Bodoquena area (Cordeiro 2008); caves are probably an important refuge for this troglophilic species during this period. 
Cordeiro L.M. et al.

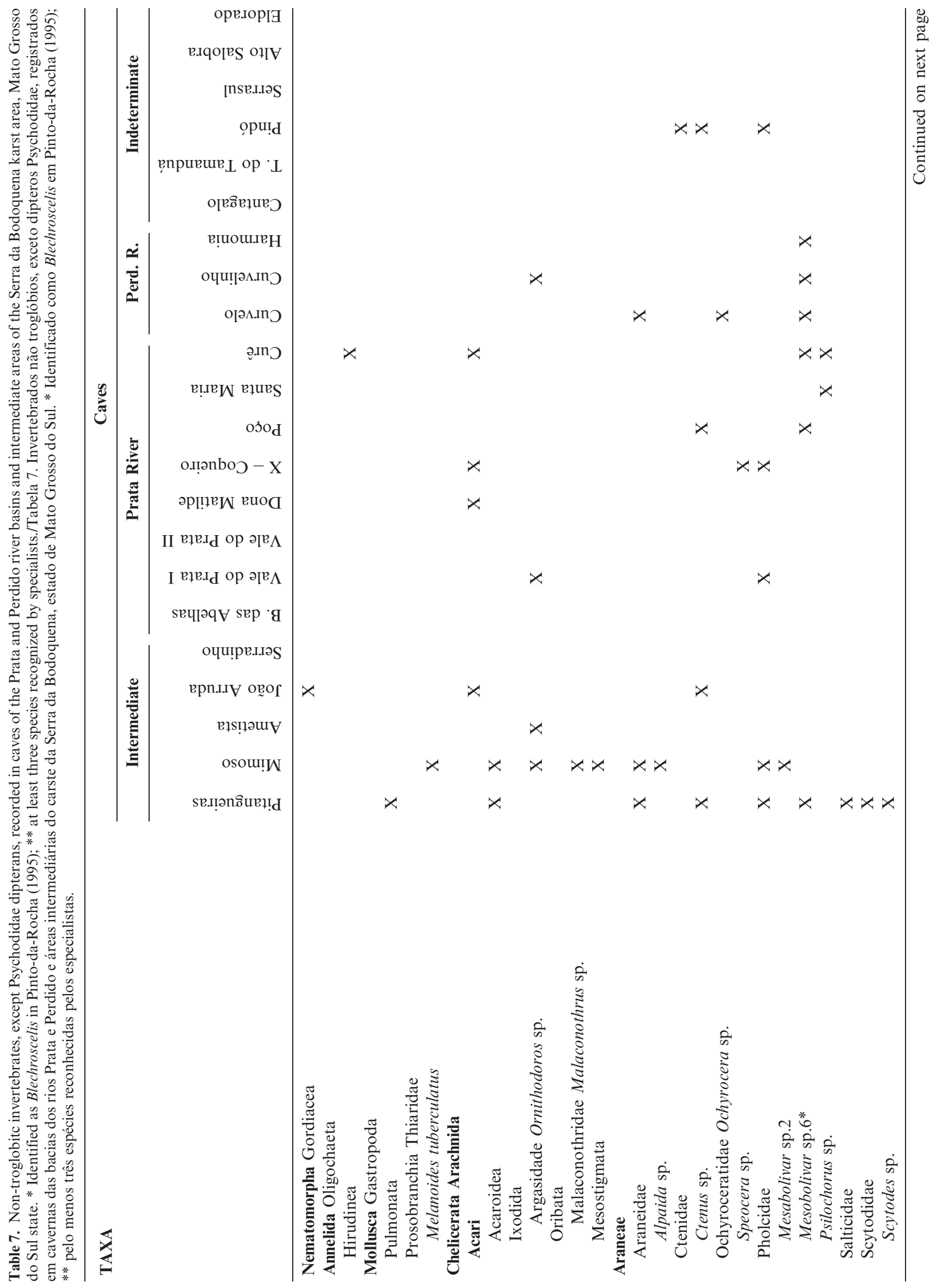




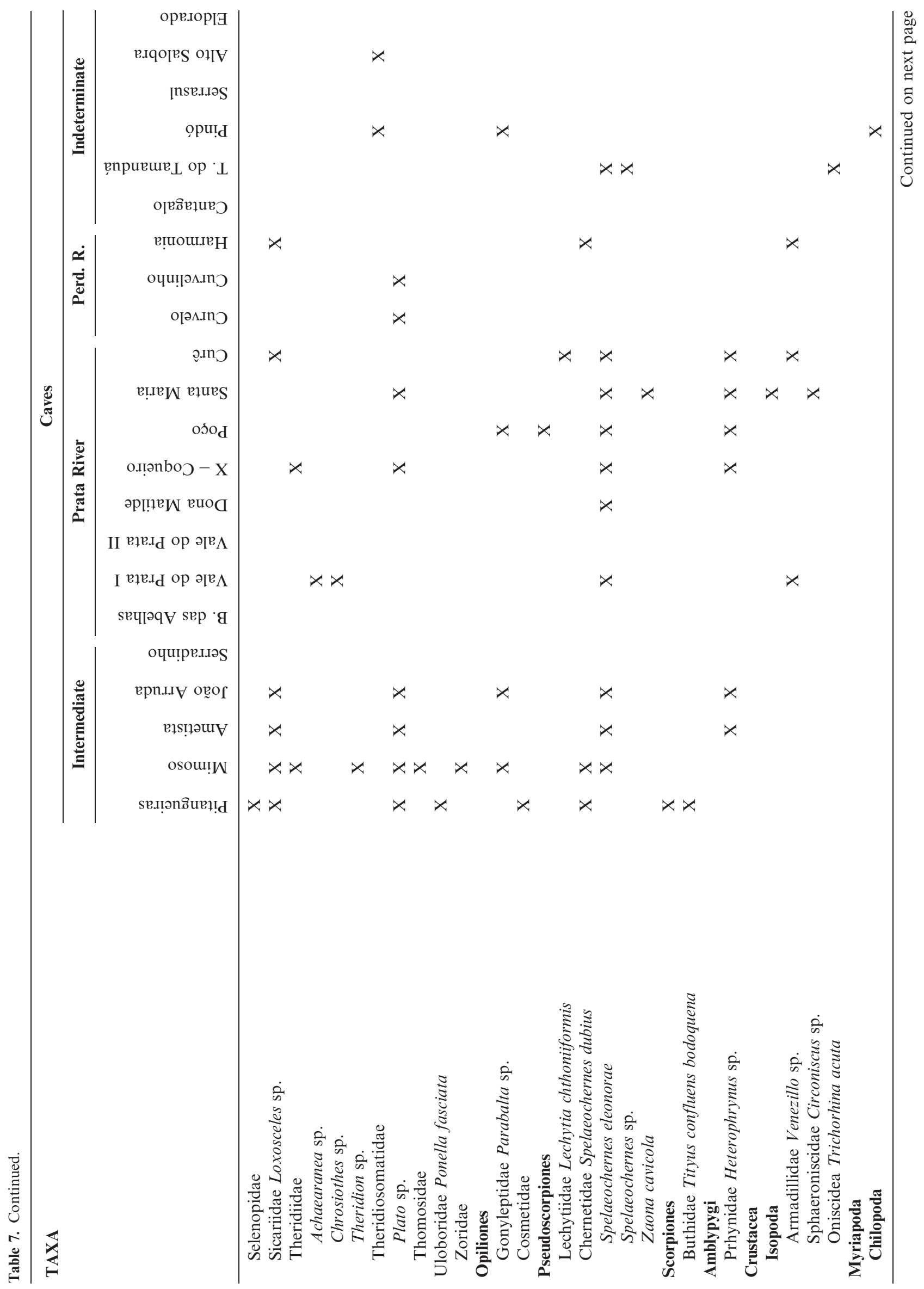


Cordeiro L.M. et al.

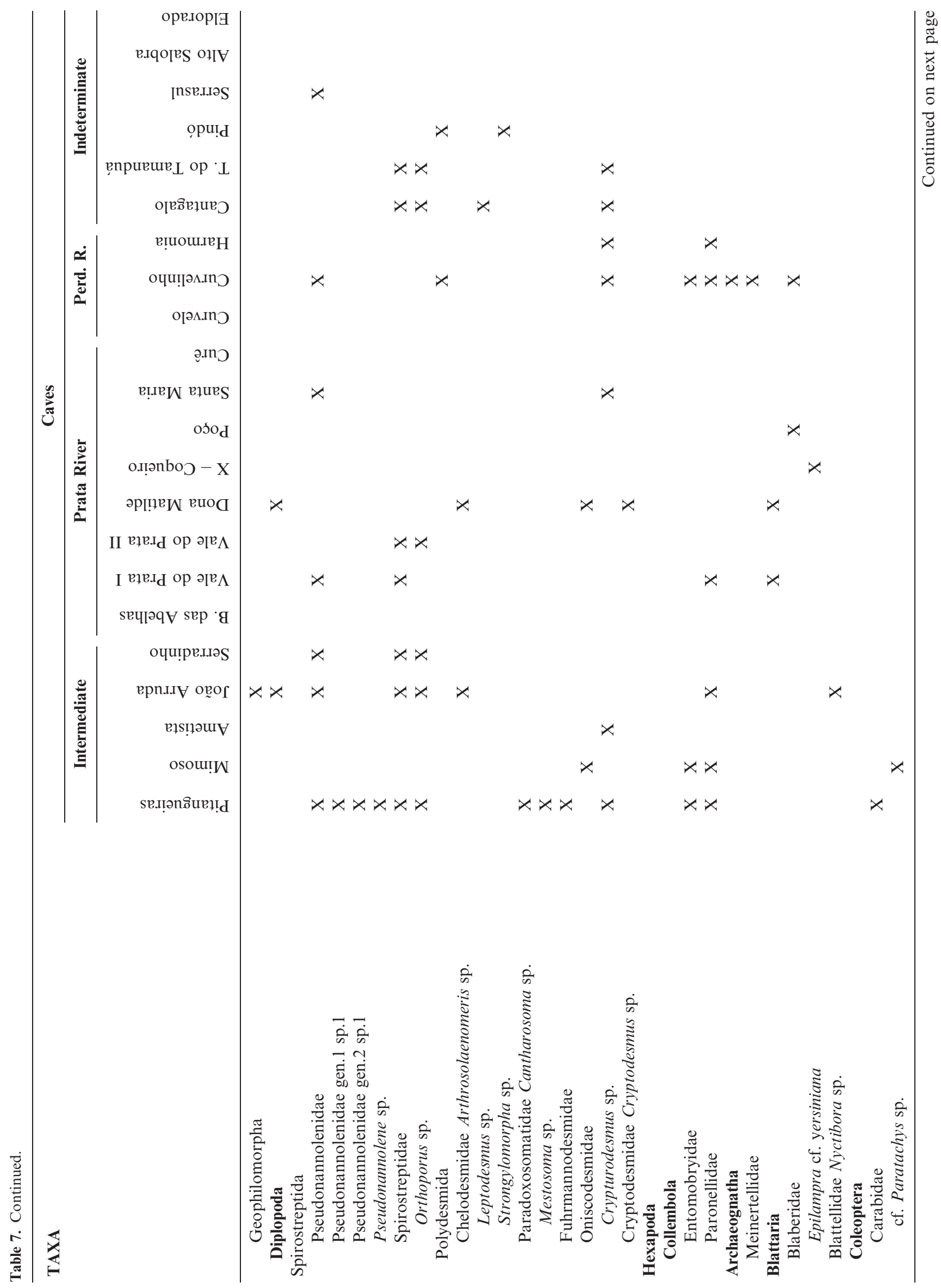


Subterranean biodiversity in the Serra da Bodoquena

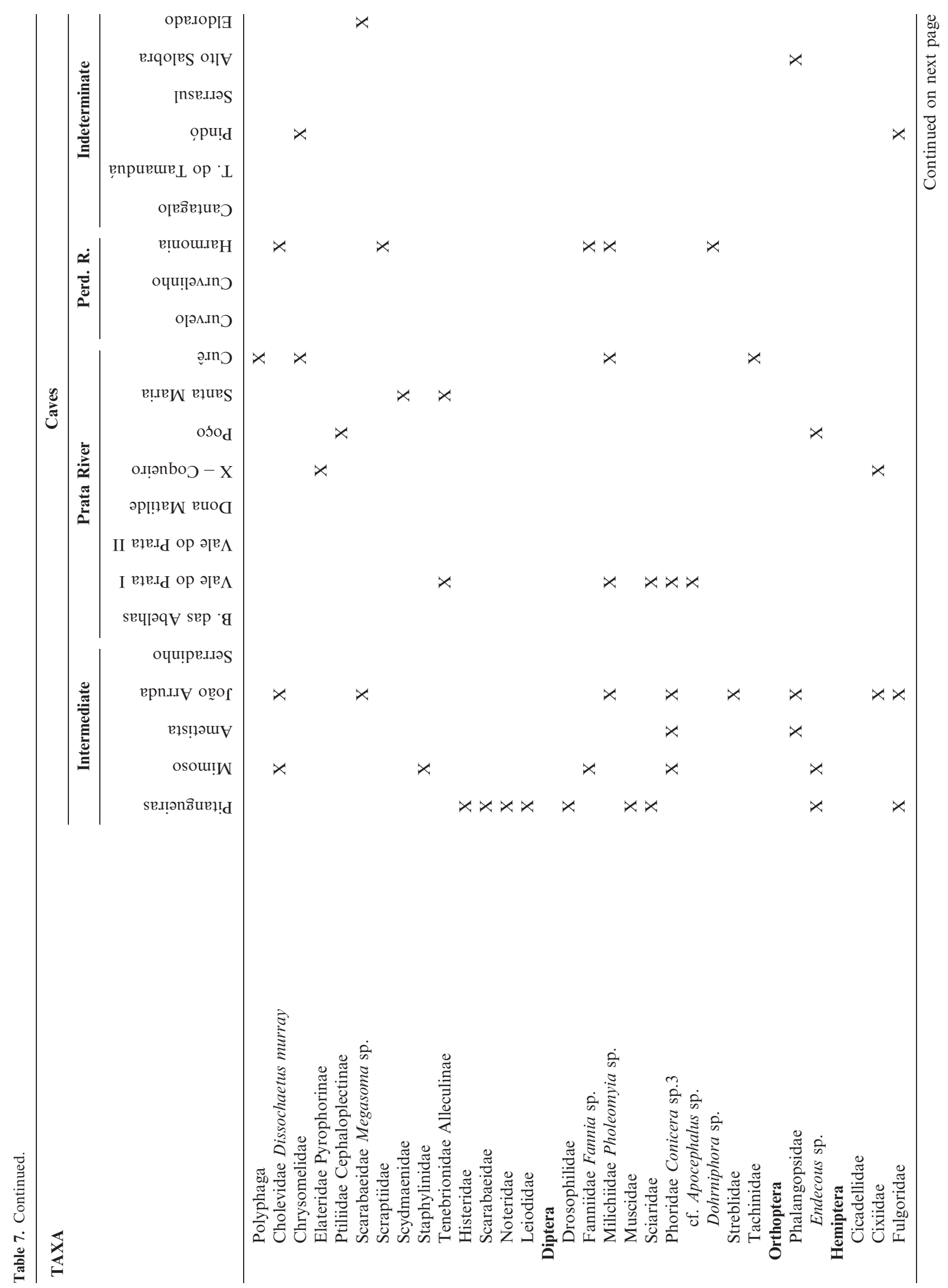


Cordeiro L.M. et al.

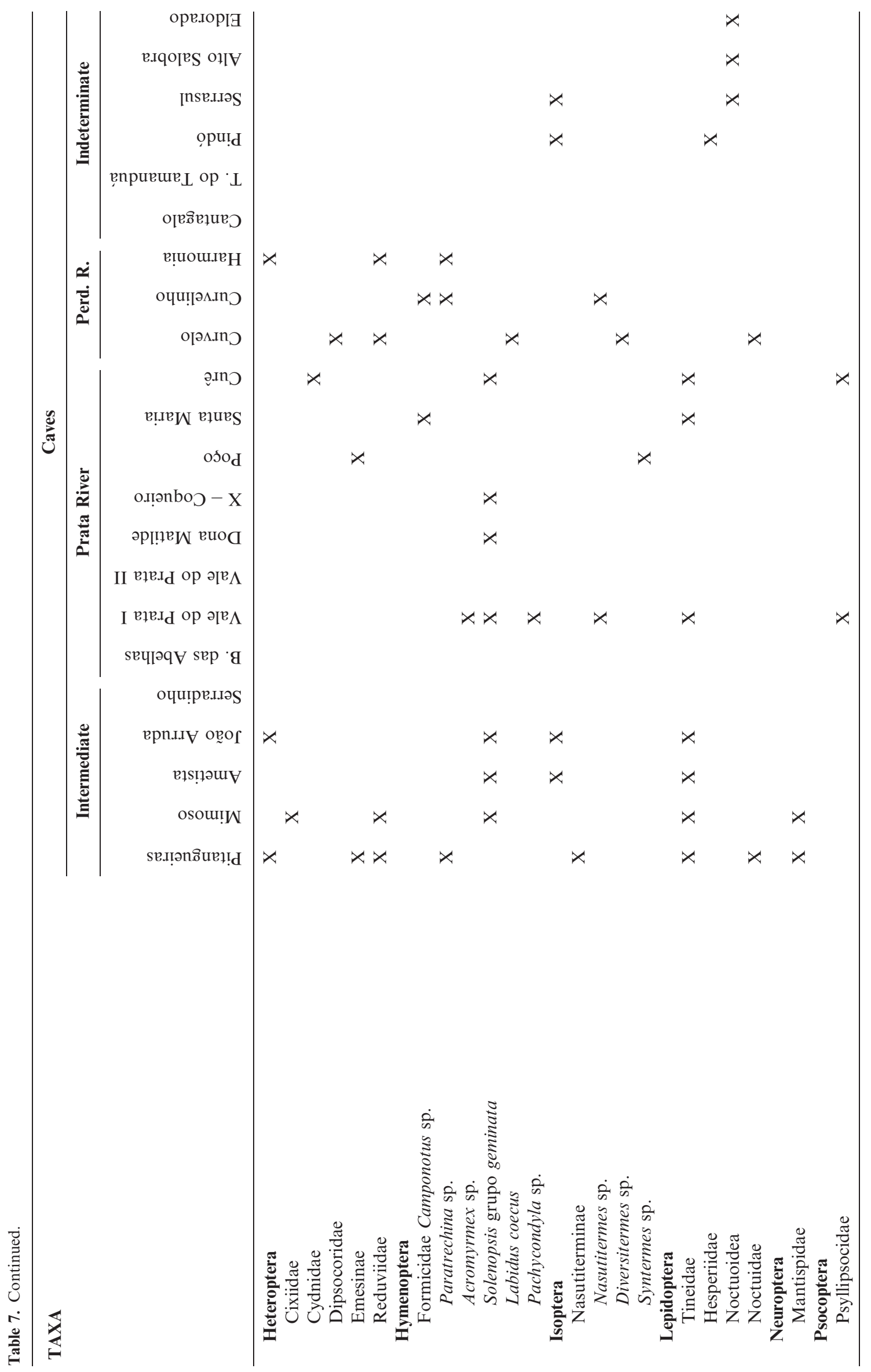


Subterranean biodiversity in the Serra da Bodoquena

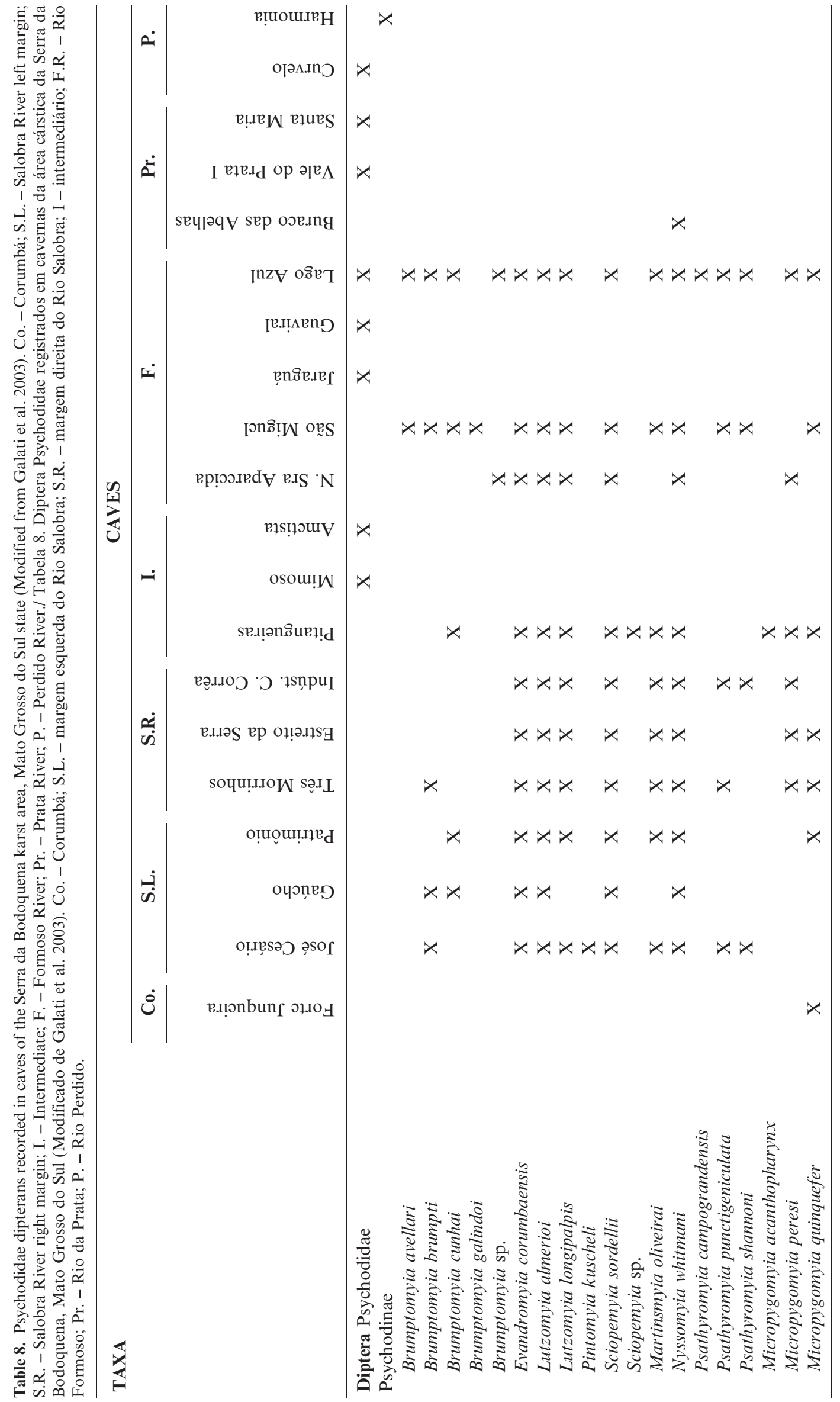


Table 9. Bats recorded in caves of the Serra da Bodoquena karst area, Mato Grosso do Sul state. S.L. - Salobra River left margin; S.R. - Salobra River right margin; I. - Intermediate; F. - Formoso River. / Tabela 9. Morcegos registrados em cavernas da área cárstica da Serra da Bodoquena, estado do Mato Grosso do Sul. S.L. - Rio Salobra margem esquerda; S.R. - Rio Salobra margem direita; I. - intermediário; F. - Rio Formoso.

\begin{tabular}{|c|c|c|c|c|c|c|c|c|c|c|c|}
\hline \multirow{3}{*}{ TAXA } & \multicolumn{11}{|c|}{ CAVES } \\
\hline & \multicolumn{3}{|c|}{ S.L. } & S.R. & \multicolumn{3}{|c|}{ I. } & \multicolumn{4}{|c|}{ F. } \\
\hline & $\begin{array}{l}\bar{\pi} \\
\text { Z } \\
Z \\
\dot{\Delta}\end{array}$ & 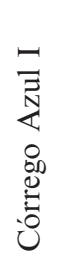 & 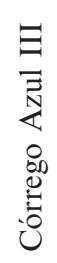 & $\frac{\mathbb{Z}}{\mathbb{Z}}$ & 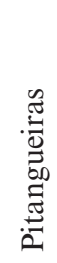 & 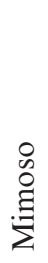 & 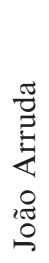 & 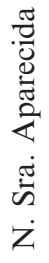 & 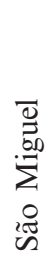 & 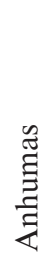 & 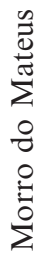 \\
\hline \multicolumn{12}{|l|}{ Mammalia Chiroptera } \\
\hline Emballonuridae Peropterix macrotis & & & & & & & & & $\mathrm{X}$ & & $\mathrm{X}$ \\
\hline Phyllostomidae Chrotopterus auritus & & & & & & $\mathrm{X}$ & & $\mathrm{X}$ & $\mathrm{X}$ & & $\mathrm{X}$ \\
\hline Desmodus rotundus & & & $\mathrm{X}$ & & $\mathrm{X}$ & $\mathrm{X}$ & & & $\mathrm{X}$ & $\mathrm{X}$ & $X$ \\
\hline Anoura geoffroyi & & & & & & $\mathrm{X}$ & & & & & \\
\hline Anoura caudifer & $\mathrm{X}$ & & & & & & & & & & \\
\hline Glossophaga soricina & & $\mathrm{X}$ & $\mathrm{X}$ & $\mathrm{X}$ & & $\mathrm{X}$ & & & $\mathrm{X}$ & & \\
\hline Carolia perspicillata & $\mathrm{X}$ & & $\mathrm{X}$ & $\mathrm{X}$ & & & & & $\mathrm{X}$ & & \\
\hline Plathyrrinus lineatus & & $\mathrm{X}$ & $\mathrm{X}$ & & & & & & & & \\
\hline Phyllostomus hastatus & & & $\mathrm{X}$ & & & $\mathrm{X}$ & & & & & \\
\hline Natalidae Natalus espiritosantensis & & & & $\mathrm{X}$ & & & $\mathrm{X}$ & & & & $\mathrm{X}$ \\
\hline
\end{tabular}

The largest dry cave in Serra da Bodoquena, Dente de Cão, with more than $2 \mathrm{~km}$ of mapped passage ways, harbors a rich troglomorphic fauna, including a new onychophoran species and arthropods such as Ctenidae spiders and Eusarcus (Gonyleptidae) opilionids, which, together with troglophilic populations, compose a unique terrestrial cave community. In Toca da Trilha cave, troglobitic velvet-worms are in syntopy with non-troglomorphic peripatids belonging to another new species, which occur at the cave entrance and the twilight zone of several caves; in one occasion, individuals of both species were observed at the same deposit of organic detritus in the twilight zone of Toca da Trilha.

\section{Phylogenetically and biogeographically relevant taxa: Spelaeogriphacea, Megagidiella, Onychophora}

The onychophorans found in caves on the Serra da Bodoquena represent a considerable extension of the distribution area for the Phyllum, and the first record of a troglobitic species for South America. There are only two other described troglobitic species of velvet worms, Peripatopsis alba Lawrence 1931, from Wynberg Cave, in the Table Mountains, South Africa, and Speleoperipatus spelaeus Peck 1975, from Pedro Great Cave, in Jamaica. Nothing was published after the original descriptions and there is no news about this material. The non-troglomorphic Epiperipatus sp. 1 (Table 3) may be troglophile since it was observed both in epigean and in aphotic habitats. It is relevant that, so far, these are the only cases of subterranean (cavernicoles sensu latu, herein defined as evolutionary units responding to subterranean selective regimens Trajano 2012) onychophorans recorded for Brazil.

The distribution of Megagidiella azul Koenemann \& Holsinger, 1999 and $P$. brasiliensis was extended to the northern plateau, encompassing now all the Bodoquena karst. In general, these species are syntopic, together with the troglomorphic planarians and oligochaetes, suggesting a responding to the same vicariant events by these invertebrates. On the other hand, in general spelaeogriphaceans are absent from caves with Trichomycterus catfish, except for Saracura (in the left margin of the Salobra river) and Abelhas (in the Prata River) caves, were the two co-occur. These patterns deserve further studies and we hypothesize that the predator effect on prey may maintain very low densities of $P$. brasiliensis when Trichomycterus are present.

The Megagidiella species from Ricardo Franco Cave has to be confirmed. On the other hand, the spelaeogriphaceans from this cave, and also from Curupira, in Mato Grosso, more than $700 \mathrm{~km}$ far from the type-locality (Lago Azul Cave) are morphological indistinguishable, all included in the nominal species Potiicoara brasiliensis (Pires-Vanin 2012). A deep phreatic connection, not demonstrated till now, could explain this exceptionally wide distribution (Pires-Vanin 2012). Other explanation is a former superficial connection, interrupted by the subsidence of the Pantanal basin, associated with a long period of evolutionary stasis, not unexpected for animals living in an exceptionally stable environment. A third hypothesis is dispersion via the hyporheic zone along the Paraguay riverbed.

\section{Ecological notes}

A marked characteristic of the Cerrado domain is an accentuated variation in the relative humidity of air between the rainy and dry seasons. Values as extreme as $4 \%$ of relative humidity in the dry winter to $80-90 \%$ in the rainy summer were recorded outside the entrances of the caves studied by Cordeiro (2008). Several invertebrates concentrate at the entrance and twilight zones during the winter, as is the case with noctuid moths, neuropterans and epigean onychophorans. An increase in faunal richness and abundance was observed in the intensively studied Córrego Azul I and Córrego III caves 
during the dry season, when a migration towards the twilight zone, up to $20 \mathrm{~m}$ far from the entrance, was recorded (Cordeiro 2008). This illustrates the importance of caves as refuges for the epigean fauna during the stressful dry and cold seasons.

Exceptionally high population densities for guanophile invertebrates have been recorded at guano deposits, such as Megagidiella amphipods reaching densities of hundreds to thousands individuals per $\mathrm{m}^{2}$ on submerged guano of hematophagous bats in Ricardo Franco Cave (Moracchioli 2002). Oniscodesmid diplopods were also observed in high densities on vampire bat guano in dry caves of the south plateau. However, it is important noting that the large populations of vampire bats in these areas are a response to the increased availability of prey represented by domestic animals, especially cattle, and do not correspond to the original condition. In undisturbed areas, such as Amazonian forests, the population densities of hematophagous bats are low. Consequently, even in caves with huge amounts of insectivorous bat guano, such as those in the Altamira-Itaituba sandstone area, hematophagous guano deposits are small and sparse (Trajano \& Moreira 1990). In natural conditions, population booms of guanophilous invertebrates associated to vampire bats would be a rare occurrence, associated to maternity colonies.

Potiicoara brasiliensis also forms very large populations and, in view of its extremely wide distribution, these crustaceans may be among the most abundant aquatic troglobites in the world (copepods excluded), if this is indeed a single species. Although not reaching the exceptional densities shown by Megagidiella sp. in Ricardo Franco cave, $P$. brasiliensis may be quite abundant in caves such as Lago Azul - maximum densities of ca. 30 individuals per $400 \mathrm{~cm}^{2}$ were recorded by Moracchioli (2002), and similar densities were observed by R.B. and L.M.C. in Cinco de Ouros and Buraco do Bicho caves. It is noteworthy that, although much more common in the typically lentic environment of submerged caves, $P$. brasiliensis has also been found in the base-level stream of Fadas cave, on the bottom of a reach with moderate water current, as also observed in the Buraco das Abelhas.

\section{Conservation: Main threats to the subterranean biodiversity in the Mato Grosso do Sul karst areas}

Subterranean ecosystems pose special problems for conservation due to their intrinsic fragility and the distinctive features of subterranean communities, including a high degree of endemism and morphological, ecological and behavioral specializations of troglobites (Bichuette \& Trajano 2010). Subterranean ecosystems in Mato Grosso do Sul, especially in the Serra da Bodoquena karst area, highly relevant in view of its biodiversity, distinguishing as a high diversity spot for troglobites, both vertebrates and invertebrates, are seriously endangered by the inappropriate use of karst landscapes.

Habitat destruction is the main threat to natural environments throughout the globe, and subterranean habitats are not exception. Irreversible habitat loss due to quarrying for cement production is the cause for subterranean biodiversity decline in karst areas, along with building of dams and reservoirs for hydro-electric power plants and water storage for human use (Bichuette \& Trajano 2010). In the Serra da Bodoquena karst area, several mining companies are prospecting or requiring licenses for mineral prospection throughout the region, mainly for carbonates and ore (BRASIL 2013). Limestone have been extensively exploited in the Serra da Bodoquena since the 1980 's, including the vicinity of the Parque Nacional da Serra da Bodoquena, without any public environmental studies (it is relevant that caves became fully protected in 1990, by Federal Decree 99.556, which made such studies mandatory for any area with speleological potential; its substitutive, Decree 6640/ 2008, kept such requirement). In the absence of previous studies, and because the areas where mining is in progress is interdict for speleologists, no information is available for such caves, therefore it is unknown how much diversity has been so far lost due to such activities in Bodoquena and Bonito County. In these cases, the lack of control and law enforcement by the authorities is an important factor responsible for subterranean diversity degradation. A similar situation concerning mining is observed in the Corumbá karst area, but the lack of knowledge (see below) does not allow for evaluation of the real or potential threats for subterranean ecosystems.

Land use in Serra da Bodoquena and Bonito area has intensified since the early $1980^{\prime}$ s as relatively small rural settlements and, a decade later, as larger farms in the higher terrains for semi-intensive livestock farming; in the last decade, soybean monoculture has been replacing cattle in the lower terrains, around Bonito Co., with even more catastrophic consequences.

Karst areas are characterized by efficient flow of groundwater through conduit systems originated by the properties of soluble rocks. Therefore, the water usually drains rapidly into the subsurface at recharge zones, through a network of fractures and cave conduits. This groundwater emerges at the surface in discharge zones through springs and wells (SallumFilho \& Karmann 2012). Removal of the surface vegetation is another global environmental threat, even more in the fragile karst landscapes, due to the predominance of groundwater drainages. This causes decrease in the nutrient input, negatively affecting the subterranean, and changes in hydrological regimes (Bichuette \& Trajano 2010).

Intensification of sedimentation, caused by human interference, mainly deforestation and livestock, were recorded during our fieldwork in caves of high hydrological and/or biological relevance, mainly in the Rio Salobra headwaters, where three undescribed troglobitic catfish occur. In Fadas Cave, Campina settlement, where the cave catfish Rhamdia and Ancistrus populations, endemic to this cave system, have been monitored since 2006, a large deposit of sediment (1.5 m height) was formed after the deforestation of one important sinkhole area located about $300 \mathrm{~m}$ upstream this cave. In Califórnia and Beija-Flor caves (systems where Trichomycterus cf. dali occurs), located in a farm where livestock is expanding, the formation of erosional craters was identified at many upstream points. These caves are major sinkholes and their streams are in advanced stages of sedimentation (Cordeiro et al. 2012)

Pumping of subterranean waters for human and livestock use, another cause for disturbance of subterranean ecosystems due to lowering of water table (Proudlove 2011, Bichuette \& Trajano 2010), is common in the Bodoquena and Bonito region as artesian and non-artesian wells; so far, no visible impact has been detected, but this potential threat must be monitored. Introduced species, recognized as a major danger for natural environments around the world, may also become a problem in some areas in the Bodoquena region, where water reservoirs ("açudes") for cattle use have been build upstream subterranean systems. During rains, fish introduced in these "açudes" enter 
caves, such as traíras (Erythrinid characiforms) and cichlids, which are predators of cavefish and other troglobitic organisms.

Alien species are harmful for aquatic indigenous and endemic fauna in fresh waters and can have a deep and pervasive effect on ecosystems that they invade (Strayer 2010). The record of Melanoides tuberculatus in Mimoso Cave, where phreatic troglobites as P. brasiliensis, M. azul and Girardia sp. also occur, is the first record of an invasive species in Brazilian groundwaters. M. tuberculatus is originally from African continent and have been responsible for total substitution of benthonic communities in surface fresh waters in North and South America (Fernandez et al. 2003, Thiengo et al. 1998). The occurrence of this alien gastropod in Mimoso Cave is recorded ten years after studies on speleogriphaceans made by Morachiolli (2002) in the same site, proving that it is a very recent invasion in this environment. The monitoring and research on population control of $M$. turberculatus is quite urgent for conservation of the endemic phreatic fauna and to understand its potential to damage the groundwater ecosystem.

Pollution of subterranean drainages, another important threat for subterranean ecosystems throughout the world (Proudlove 2001, Bichuette \& Trajano 2010), is also concern in the Serra da Bodoquena region. Use of dolines for garbage dumping has been observed in several settlements, such as the Campina. Pollution by detergents, largely used in settlements, may have a deleterious impact on subterranean fish due to interference on their natural behavior (Trajano 1997). Nitrogen derivates, bacteria such as fecal coliforms and chemical residues of drugs used in livestock accumulate in the subsurface. Due to the hydrological characteristics of the karst, pollutants spread fast and widely in groundwaters. In the Bonito County surroundings, the substitution of livestock by soybean monocultures have a great potential to deteriorate even more the quality of underground waters due to the use of large amounts of pesticides, which may contaminate springs and wells, calling for attention and serious actions by the authorities.

Tourism is a major economic activity in the region, especially in Bonito, where caves receive thousands of tourists every year. Therefore, the demand for caves with potential tourist use is increasing and visitation to caves not open to tourism is a recurrent problem. Negative consequences of visitation are: topoclimatic changes, introduction of alien species, including pathogens, and materials (such as metal, cement and treated wood), pollution by items left in caves, soil compacting and trampling of cavernicoles, destruction of specific microhabitats and direct disturbance of fauna (lights, loud noises, handling of specimens) (Trajano 2000). Dente de Cão and Urubu Rei are examples of diversified ecosystems endangered by uncontrolled human visitation.

For a discussion on environmental problems affecting subterranean habitats in Mato Grosso do Sul, see also Cordeiro et al. (2013).

In conclusion, Serra da Bodoquena, the largest and by far the best known karst area in Mato Grosso do Sul, is undoubtedly a priority area for conservation in Brazil, requiring urgent actions for effective protection of its subterranean ecosystems, many of which are endangered. The Park area must be increased, and its limits expanded in order to encompass the headwaters and recharge areas of the main subterranean systems, and, in the occupied areas, other categories of conservation units should be created to guarantee a sustainable use of the land. More attention should be paid to the settlements by the authorities, providing education, health and sanitary conditions adequate to the karst terrain. In addition to environment studies to fulfill the legal requirements in areas of economic interest, and a serious effort by the authorities to enforce such regulations and properly control cave visitation, a responsible attitude by the media is fundamental, in order to broadcast correct information, not distorted by sensationalism, always with the objective of preserving the subterranean biodiversity of Mato Grosso do Sul.

\section{Final considerations}

\section{Perspectives for speleobiology in Mato Grosso do Sul}

The major bottleneck for the progress of the speleobiology in Mato Grosso do Sul, as generally in Brazil, is taxonomic impediment. Therefore, the investment on the formation of taxonomists is of paramount importance.

The faunistic data reunited here allows for a first approach on the taxonomic diversity at the alfa (local) level, in a spatial scale. As a next step to describe the structure and functioning of subterranean ecosystems in the Bodoquena area, long term studies in selected caves are needed in order to detect temporal patterns. In addition, additional collections are needed for taxonomic studies of many taxa. As well, the addition of new caves, especially in the least known southern plateau, will allow to verify the relationship between local and regional species richness.

However, considering only the observed local diversity is not enough because taking into account only the number of species and their relative contribution have little predictive power about the functioning of the communities. A very promising research field is to compare functional and phylogenetic diversity of different types of caves in relation to epigean habitats geographically continuous. Widely distributed nominal species (e.g., Potiicoara brasiliensis) or species groups (Megagidiella, Trichomycterus) are excellent models for phylogeographic analyses associated to detailed morphological studies.

Genera with both troglobitic and troglophilic populations, such as ctenid spiders, Eusarcus opilionids and onychophorans, offer good opportunities for comparative studies focusing on genetics, biology, physiology and behavior. On the other hand, the relictual character of several troglobites, specially the aquatic ones, without living epigean relatives in the area, poses difficulties for such studies.

Other cave areas in Mato Grosso do Sul are barely known. Speleobiological studies are lacking in the Corumbá area and the Serra do Amolar, northwestern MS, both with exposed limestones and iron rocks in the vicinity, and in the sandstones of Serra de Maracajú.

\section{Main collections:}

After study, the material collected in subterranean habitats is send to official collections of institutions registered at the CNPQ - Conselho Nacional de Pesquisa and CGEN Conselho de Gestão do Patrimônio Genético, mainly the Museu de Zoologia da Universidade de São Paulo - MZUSP, the Museu Biológico do Instituto Butantã, the Museu Nacional do Rio de Janeiro - MNRJ and Coleção do Zoológica da Universidade Federal do Mato Grosso do Sul - ZUFMS. 
During studies, the specimens are kept in the institutions of the respective specialists; small reference collections are in the authors' institution for comparison and training.

\section{Acknowledgements}

We are especially indebted to the colleagues and students who made collections and preliminary identifications, providing original data on several caves (e.g., Anhumas, Mimoso, Buraco das Abelhas, Lago Azul, Nossa Senhora Aparecida, Pitangueiras, Curê, Tamanduá), especially to Edmundo Dinelli Costa-Junior, Regina Bessi, Sandro Secutti, Cristina Rheims, Marcos Ryotaro Hara, Fabiana C. Pioker, Melissa Regina Pioker and Jean-Jacques Geoffroy. Thanks are also due to the speleologists who helped us in the fieldwork, in special Bruna M. Cordeiro, the Grupo de Espeleologia da Serra da Bodoquena, César Augusto Miner (GBPE), José Guilherme (PNSB) and Suzana Escarpinati (UFGD). The authors acknowledge the specialists who helped with the identifications: Antônio Brescovit and Igor Cizauskas (Araneae), Cibele Bragagnolo, Ricardo Pinto da Rocha and Marcos Hara (Opiliones), João Paulo Barbosa (Diplopoda), Gustavo Graciolli (Diptera), Regina Bessi and Sérgio Vanin (Coleoptera), Marcio Bolfarini (Ensifera), Gilmar Neves (Copepoda) and Luiz Ricardo L. Simone (Mollusca). Gustavo Graciolli also for the constructive ideas in previous version of this manuscript. William Sallun Filho for the help with geological map and caves coordinates. The collections were authorized by IBAMA/SISBio and PNSB (E.T. and colaborators, licenses $N^{\circ}$ 051-DIFAP/IBAMA de 09/05/2006, 089-DIFAP-IBAMA de 21/07/2005, 137/2004-CGFAU/LIC, 0023/03-CECAV/DIREC，004/02-CECAV/DIREC，063/2001DIFAS/DIREC, 027/2000-DIFAS/DIREC; L.M.C., R.B, ET. 22892-1 ICMBIO/SISBIO). The cave diving activities were authorized by PNSB/ICMBio ( ${ }^{\circ}$ 02091.000005/2012-38) and guided by Tuta Barroco. This work was supported by FUNDECT/MS (L.M.C. Ms.c. Grant 41/100.082-2005), CNPQ (E.T., Grant n. 303362/2007-3; L.M.C. PhD Grant 143379/2009-7), FAPESP (R.B. Grant n. 2010/03084-2), IB/ USP, CAPES-PROEX.

\section{References}

ANDRADE, R.M.G., GALATI, E.A.B. \& TAMBOURGI, D.V. 2001 Presença de Loxosceles similis Moenkhaus, 1898 (Araneae, Sicariidae) na Serra da Bodoquena, Estado de Mato Grosso do Sul, Brasil. Rev. Soc. Bras. Med. Trop. 34: 275-277, http:// dx.doi.org/10.1590/S0037-86822001000300008

BIZZI, L.A., SCHOBBENHAUS, C., GONÇALVES, J.H., BAARS, F.J., DELGADO, I.M., ABRAM, M.B., NETO, R.L., MATOS, G.M.M. \& SANTOS, J.O.S. 2001. Geologia, Tectônica e Recursos Minerais do Brasil: Sistema de Informações Geográficas - SIG e Mapas na escala 1: 2.500.000, Brasília.

BOGGIANI, P.C. \& CLEMENTE, J. 1999. A questão do Licenciamento Ambiental de empreendimentos turísticos no Planalto da Bodoquena - Mato Grosso do Sul. Rev. Geogr. 2: 29-40.

BORGHEZAN, R. 2008. Caracterização da ictiocenose em poções da Gruta das Fadas e aspectos biológicos de Rhamdia sp. (Siluriformes: Heptapteridae) e Ancistrus sp. (Siluriformes: Loricariidae), Serra da Bodoquena, Mato Grosso do Sul. Monografia, Universidade para o Desenvolvimento do Estado e da Região do Pantanal, Campo Grande.

BRASIL. 2013. Departamento Nacional de Produção Mineral Sistema de informações geográficas da mineração. http://www. dnpm.gov.br (last accessed in 03/11/2013).
CAMPANHA, G.A.C., BOGGIANI, P.C., SALLUN-FILHO, W., SÁ, F.R., ZUQUIM, M.P.S. \& PIACENTINI, T. 2011. A Faixa de Dobramento Paraguai na Serra da Bodoquena e Depressão do Rio Miranda, Mato Grosso do Sul. Geol. USP, Sér. Cient. 11(3):79-96, http://dx.doi.org/10.5327/Z1519-874X2011000300005

CORDEIRO, L.M.. 2008. Fauna cavernícola da Serra da Bodoquena: revisão bibliográfica e um estudo de ecologia de comunidades. Dissertação, Universidade Federal do Mato Grosso do Sul, Campo Grande.

CORDEIRO, L.M., BORGHEZAN, R, TRAJANO, E., ESCARPINATI, S., MARQUES, K. 2012. The silence degradation in the water paradise: Sedimentation in caves of Serra da Bodoquena karst area, State of Mato Grosso do Sul, NW Brazil. In: 49th Annual Meeting of the Association for Tropical Biology and Conservation - Abstracts, Bonito. http://www.atbc2012.org/ (last accessed in 10/09/2012).

CORDEIRO, L.M., Borghezan \& TRAJANO, E. 2013. Distribuição, riqueza e conservação dos peixes troglóbios da Serra da Bodoquena, MS, Brasil (Teleostei: Siluriformes). Rev. Biol. 10(2): 21-27.

COSTA, JR., E. 2004. Fish from the Underwater Caves of Bodoquena Plateau, Mato Grosso do Sul, Southwestern Brazil. DIR Lifestyle \& Underwater Adventure Magazine. 5:8-12.

ERIKSSON, A. \& GONÇALVES, F. 2010. Síntese do conhecimento da fauna de morcegos cavernícolas na Serra da Bodoquena. O Carste. 22(2):39-42.

FERNANDEZ, M.A., THIENGO, S.C. and SIMONE, L.R.L. 2003. Distribution of the introduced freshwater snail Melanoides tuberculatus (Gastropoda: Thiaridae) in Brazil. Nautilus. 117: 78-82.

FORD, D. \&WILliAMS, P. 2007. Karst Hydrogeology and Geomorphology. Wiley, Chichester.

GALATI, E.B., NUNES, V.L.B., BOGGIANI, P.C., DORVAL, M.E.C., CRISTALDO, G., ROCHA, H.C., OSHIRO, E.T., ANDRADE, R.M.G. \& NAUFEL, G. 2003. Phlebotomines (Diptera, Psychodidae) in caves of the Serra da Bodoquena, Mato Grosso do Sul State, Brazil. Rev. Bras. Entomol. 47:283-296, http://dx.doi.org/10.1590/S0085-56262003000200017

GNASPINI, P. \& TRAJANO, E. 1994. Brazilian cave invertebrates, with a checklist of troglomorphic taxa. Rev. Bras. Entomol. 38(3/4):549-584.

GNASPINI, P., TRAJANO, E. \& SANCHEZ, L.E. 1994. Província Espeleológica da Serra da Bodoquena, MS: exploração, topografia e biologia. Espeleo-tema 17:19-44.

GODOY, N.M. 1986. Nota sobre a fauna cavernícola de Bonito, MS. Espeleo-tema 15:80-92.

LABRUNA, M.B. \& VENZAL, J.M. 2009. Carios fonsecai sp. nov. (Acari, Argasidae), a bat tick from the central-western region of Brazil. Acta parasitol. 54(4):355-363.

MAHNERT, V.. 2001. Cave-dwelling pseudoscorpions (Arachnida, Pseudoscorpiones) from Brazil. Rev. Suisse Zool. 108:95-148.

MORACCHIOLI, N.. 2002. Estudo dos Spelaeogriphacea brasileiros, crustáceos Peracarida subterrâneos. Tese de Doutoramento. Instituto de Biociências da Universidade de São Paulo, São Paulo, Brazil.

PINTO-DA-ROCHA, R.. 1995. Sinopse da fauna cavernícola do Brasil (1907-1994). Pap. Avulsos Zool. 39:61-173.

PINTO-DA-ROCHA, R. \& SOSSEGOLO, G.C. 2001. Estudo da fauna da gruta de São Miguel I, Serra da Bodoquena (MS), como subsídio para o plano de manejo. In: Org. Grupo de Estudos Espeleológicos do Paraná - Açungui, Conservando cavernas: 15 anos de espeleologia, Curitiba, p.125-135.

PIRES-VANIN, A.M.S. 2012. The discovery of male Potiicoara brasiliensis (Crustacea, Spelaeogriphacea) with notes on biology and distribution. Zootaxa 3421:61-68.

PROUDLOVE, G S. 2001. The conservation status of hypogean fishes. Environ. Biol. Fish. 62:201-213, http://dx.doi.org/10.1023/ A:1011828726038 
SALLUN FILHO, W, KARMANN, I \& LOBO, H.A.S. 2010. Cavernas na Serra da Bodoquena. O Carste 22(2):27-33.

SALLUN FILHO, W, KARMANN, I, PETRI, I \& UTIDA, G. 2009. A deposição de tufas quaternárias no estado de Mato Grosso do Sul: Proposta de definição da Formação Serra da Bodoquena. Geol. USP, Sér. Cient. 9(3):47-60, http://dx.doi.org/10.5327/Z1519874X2009000300003

SALLUN FILHO, W \& KARMANN, I. 2012. Províncias cársticas e cavernas do Brasil. In: Geologia do Brasil. 629-641.

SALLUN FILHO, W \& KARMANN, I. 2007. Geomorphological map of the Serra da Bodoquena karst, west-central Brazil. Journal of Maps 2007:282-295.

SALLUN FILHO, W, Karmann, I. \& BOGGIANI, P.C. 2004. Paisagens cársticas da Serra da Bodoquena (MS). In (Mantesso Neto, V, Bartorelli, A, Carneiro, C.D.R. \& Brito Neves, B.B orgs). Geologia do continente Sul-americano: evolução da obra de Fernando Flávio Marques de Almeida. 1 ed. São Paulo, 424-433.

SBE - Sociedade Brasileira de Espeleologia.Cadastro Nacional de Cavernas. http://www.sbe.com.br/cnc. (last access in 30/08/2012).

SCREMIN-DIAS, E., POTT, V.J., SOUZA, P.R. \& HORA, R.C. 1999. Nos Jardins Submersos da Bodoquena: Guia para Identificação das Plantas Aquáticas de Bonito e Região de Bonito/MS. Editora da Universidade Federal de Mato Grosso do Sul, Campo Grande.
STRAYER, D.L. 2010. Alien species in fresh waters: ecological effects, interactions with other stressors, and prospects for the future. Freshwater Biol. 55: 152-174, http://dx.doi.org/10.1111/j.13652427.2009.02380.x

THIENGO, S.C., FERNANDEZ, M.A., BOAVENTURA, M.F., STORTTI, M.A. 1998. A Survey of gastropods in the Microrregião Serrana of Rio de Janeiro, Brazil. Mem. I. Oswaldo Cruz. 93: 233234, http://dx.doi.org/10.1590/S0074-02761998000700041

TRAJANO, E. 1997. Threatened fishes of the World: Pimelodella kronei (Ribeiro, 1907). Environ. Biol. Fish. 49:332-332, http:// dx.doi.org/10.1023/A:1007353902363

TRAJANO, E. 2001. Ecology of subterranean fishes: an overview. Environ. Biol. Fish. 62:133-160, http://dx.doi.org/10.1023/A:1011841913569

TRAJANO, E. 2012. Ecological classification of subterranean organisms. In: WHITE, W.B. \& CULVER D.C. (EDS.) ENCYCLOPEDIA OF, C.a.v.e.s. Ed. Elsevier Amsterdam, p.275-277.

TRAJANO, E., MOREIRA, J.R.A. 1991. Estudo da fauna de cavernas da Província Espeleológica Arenítica Altamira-Itaituba. Rev. Bras. Biol. 51(1)13-29.

TRAJANO, E., GOLOVATCH, S.I., GEOFFROY, J.J., PINTO-DAROCHA, R. \& FONTANETTI, C.S. 2000. Synopsis of Brazilian cave-dwelling millipedes (Diplopoda). Pap. Avulsos Zool. 41:259_ 287. 